Article

\title{
Highly Linear Polyethylenes Achieved Using Thermo-Stable and Efficient Cobalt Precatalysts Bearing Carbocyclic-Fused NNN-Pincer Ligand
}

\author{
Jingjing Guo ${ }^{1,2}$, Zheng Wang ${ }^{2} \mathbb{C}$, Wenjuan Zhang ${ }^{1, *}$, Ivan I. Oleynik ${ }^{3, *} \mathbb{*}$, \\ Arumugam Vignesh ${ }^{2}$, Irina V. Oleynik ${ }^{3}$,, Xinquan $\mathrm{Hu}^{4, *}$, Yang Sun ${ }^{2}$ and Wen-Hua Sun ${ }^{2, *}$ \\ 1 Beijing Key Laboratory of Clothing Materials R\&D and Assessment, Beijing Engineering Research Center of \\ Textile Nanofiber, School of Materials Science and Engineering, Beijing institute of Fashion Technology, \\ Beijing 100029, China; jingguo1995@163.com \\ 2 Key Laboratory of Engineering Plastics and Beijing National Laboratory for Molecular Science, Institute of \\ Chemistry, Chinese Academy of Sciences, Beijing 100190, China; wangzheng@iccas.ac.cn (Z.W.); \\ avignesh@iccas.ac.cn (A.V.); sy0471103@iccas.ac.cn (Y.S.) \\ 3 N.N. Vorozhtsov Novosibirsk Institute of Organic Chemistry, Pr. Lavrentjeva 9, Novosibirsk 630090, Russia; \\ olk@nioch.nsc.ru \\ 4 College of Chemical Engineering, Zhejiang University of Technology, Hangzhou 310014, China \\ * Correspondence: zhangwj@bift.edu.cn (W.Z.); oleynik@nioch.nsc.ru (I.I.O.); xinquan@zjut.edu.cn (X.H.); \\ whsun@iccas.ac.cn (W.-H.S.); Tel.: +86-10-62659707 (W.Z.); +7-383-330-9524 (I.I.O.); +86-571-88320103 (X.H.); \\ +86-10-6255-7955 (W.-H.S.)
}

Academic Editor: Giovanni Ricci

Received: 13 March 2019; Accepted: 21 March 2019; Published: 25 March 2019

check for updates

\begin{abstract}
Six examples of 2-(1-arylimino)ethyl-9-arylimino-5,6,7,8-tetrahydrocycloheptapyridinecobalt(II) chloride complexes, [2-(1-ArN) $\mathrm{C}_{2} \mathrm{H}_{3}-9-\mathrm{ArN}-5,6,7,8-\mathrm{C}_{5} \mathrm{H}_{8} \mathrm{C}_{5} \mathrm{H}_{3} \mathrm{~N}_{\mathrm{C}} \mathrm{CoCl}_{2}$, $\left(\mathrm{Ar}=2-\left(\mathrm{C}_{5} \mathrm{H}_{9}\right)-6-\mathrm{MeC}_{6} \mathrm{H}_{3} \quad \mathrm{Co1}, \quad 2-\left(\mathrm{C}_{6} \mathrm{H}_{11}\right)-6-\mathrm{MeC}_{6} \mathrm{H}_{3} \quad \mathrm{Co2}, \quad 2-\left(\mathrm{C}_{8} \mathrm{H}_{15}\right)-6-\mathrm{MeC}_{6} \mathrm{H}_{3} \quad \mathrm{Co}\right.$, 2- $\left(\mathrm{C}_{5} \mathrm{H}_{9}\right)-4,6-\mathrm{Me}_{2} \mathrm{C}_{6} \mathrm{H}_{2}$ Co4, 2- $\left(\mathrm{C}_{6} \mathrm{H}_{11}\right)-4,6-\mathrm{Me}_{2} \mathrm{C}_{6} \mathrm{H}_{2}$ Co5, and 2- $\left(\mathrm{C}_{8} \mathrm{H}_{15}\right)-4,6-\mathrm{Me}_{2} \mathrm{C}_{6} \mathrm{H}_{2}$ Co6), were synthesized by the direct reaction of the corresponding ortho-cycloalkyl substituted carbocyclic-fused bis(arylimino)pyridines (L1-L6) and cobalt(II) chloride in ethanol with good yields. All the synthesized ligands (L1-L6) and their corresponding cobalt complexes (Co1-Co6) were fully characterized by FT-IR, ${ }^{1} \mathrm{H} /{ }^{13} \mathrm{C}-\mathrm{NMR}$ spectroscopy and elemental analysis. The crystal structure of $\mathbf{C o} 2$ and $\mathbf{C o} 3$ revealed that the ring puckering of both the ortho-cyclohexyl/cyclooctyl substituents and the one pyridine-fused seven-membered ring; a square-based pyramidal geometry is conferred around the metal center. On treatment with either methylaluminoxane (MAO) or modified methylaluminoxane (MMAO), all the six complexes showed high activities (up to $4.09 \times 10^{6} \mathrm{~g}$ of $\mathrm{PE}$ $\mathrm{mol}^{-1}(\mathrm{Co}) \mathrm{h}^{-1}$ ) toward ethylene polymerization at temperatures between $20^{\circ} \mathrm{C}$ and $70{ }^{\circ} \mathrm{C}$ with the catalytic activities correlating with the type of ortho-cycloalkyl substituent: Cyclopentyl (Co1 and Co4) > cyclohexyl (Co2 and Co5) > cyclooctyl (Co3 and Co6) for either R = H or Me and afforded strictly linear polyethylene $\left(T_{\mathrm{m}}>130{ }^{\circ} \mathrm{C}\right)$. The narrow unimodal distributions of the resulting polymers are consistent with single-site active species for the precatalyst. Furthermore, compared to the previously reported cobalt analogues, the titled precatalysts exhibited good thermo-stability (up to $70{ }^{\circ} \mathrm{C}$ ) and possessed longer lifetime along with a higher molecular weight of PE $\left(M_{\mathrm{W}}\right.$ : 9.2 25.3 $\left.\mathrm{kg} \mathrm{mol}^{-1}\right)$.
\end{abstract}

Keywords: highly linear polyethylene; vinyl-end polyethylene; cobalt precatalyst; thermo-stable and efficient catalysis; correlation between structure and activity 


\section{Introduction}

Over the past two decades ago, Brookhart [1,2] and Gibson [3-5] independently discovered the well-defined bis(imino)pyridine-cobalt and -iron complexes (A) as highly active precatalysts for ethylene oligo-/polymerization. In the intervening years, large numbers of different skeletal modifications, such as changes to the $N$-aryl groups and the backbone of pyridine, have been made to the bis(imino)pyridine scaffolds (A, Chart 1) [6-15], culminating in improvements to both catalytic activity and thermal stability [6,16-33]. The related progress was collected in several reviews [6,9-11,14,15].

To enhance the thermal stability, one efficient method was introduced to the bulky substituent on the ortho-position of $N$-aryl group [6-15] (Chart 1). Wu's group have reported that bis(imino)pyridine iron complexes (A1) bearing a bulky 2-methyl-6-sec-phenethyl group, can produce linear high molecular weight polyethylene with higher activity at elevated temperature [31]. In the recent five years or so, our group have developed series of dibenzhydryl substituted bis(imino)pyridyl iron and cobalt complexes (A2) that displayed good catalytic activity at high temperature and explored a very good thermal stability [34]. There were also reports about incorporating the cycloalkyl substituents in the 2,6-positions of the $N$-aryl groups of the bis(imino)pyridine (A3) and it has been found to efficiently increase the temperature stability of the iron catalysts over their alkyl analogues [35]. Later Russia's group documented the 2,6-bis(arylimino)pyridy liron(II) chloride complexes by the introduction of cycloaliphatic substituents into the ortho position of the aryl groups substantially enlarges the temperature interval of efficient use of the related catalysts for ethylene polymerization reactions [36]. Consequently, they have prepared the multifunctional bis(imino)pyridine iron chloride complexes incorporating the cycloalkyl substituent that could display more efficient ethylene polymerization at elevated temperatures $\left(60-90^{\circ} \mathrm{C}\right)$ while retaining high molecular weights of the resulting PE, as distinct from the analogous monofunctional systems (A3) [37].

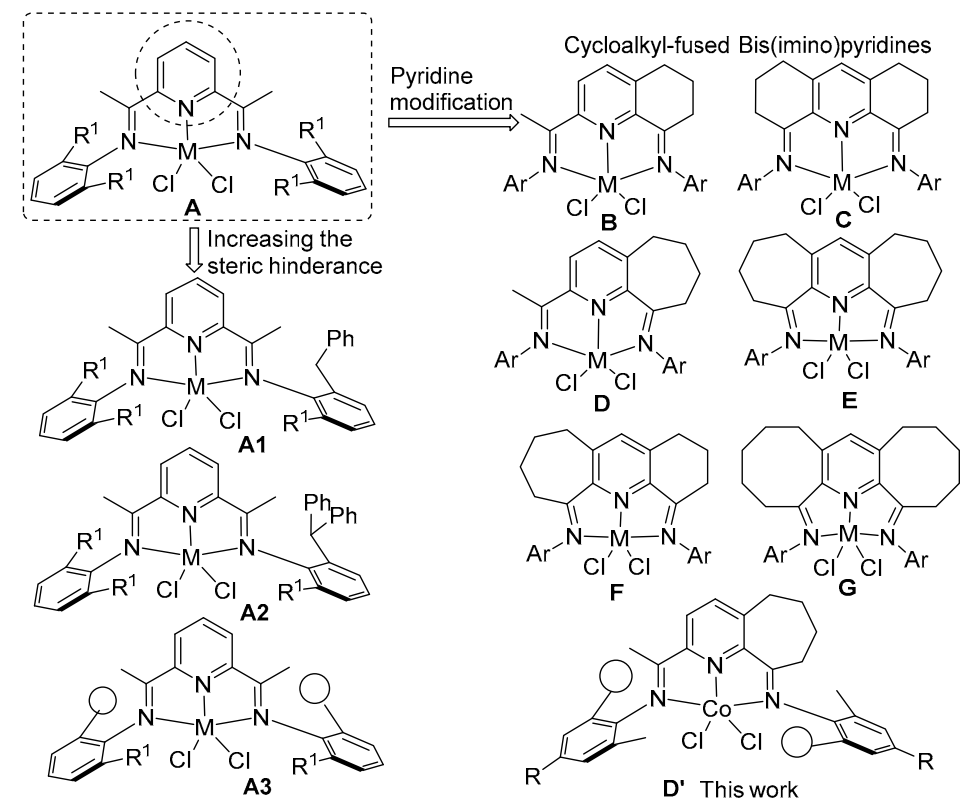

Chart 1. Bis(imino)pyridine cobalt complexes and cycloalkyl ring fused derivatives.

On the other hand, the modification of bis(imino)pyridine backbone to enhance the catalytic properties at a higher temperature. Our group has been interested in introducing cycloalkyl unit to bis(imino)pyridine ligand sets by adjusting the flexibility of the exterior imine donors to modify the donor properties of the NNN-pincer ligand set and in-turn the performance of the catalyst [6]. With regards to cobalt precatalysts (Chart 1), one [38-42] or two [43-48] cycloalkyl unit fused derivatives having ring sizes between five and eight are accessible (see for example B [39], C [40], D [41], E [43,44], F [45], and G [47,48], Chart 1). In terms of catalytic performance and the polymeric products 
properties, we have observed significant differences between cobalt catalysts (B-G). For example, five-membered ring fused bis(imino)pyridine cobalt precatalyst [38], showed lower activities $(2.89 \times$ $10^{4} \mathrm{~g}$ of $\mathrm{PE} \mathrm{mol}^{-1}(\mathrm{Co}) \mathrm{h}^{-1}$ ) than their analogues of $\mathbf{A}$ and $\mathbf{B}-\mathrm{G}$ [6]; while using $\mathbf{B}$ that containing slightly larger six-membered ring (Chart 1) [39], results in much higher activities (up to $1.08 \times 10^{7} \mathrm{~g}$ of PE mol${ }^{-1}$ (Co) $\mathrm{h}^{-1}$ ) and better thermal stability than $\mathbf{A}$ and $\mathbf{C}[4,6,39,40]$, and produces polyethylene wax with narrower molecular weight distribution. Expanding the ring size to seven (D and E, Chart 1) [41,43,44], the more flexible structure, leads to increased molecular weight $\left(M_{\mathrm{w}}\right.$ up to $\left.54.0 \mathrm{~kg} \mathrm{~mol}^{-1}\right)$ which is most apparent with doubly-fused $\mathbf{E}$ containing ortho-cycloalkyl substituent, but $\mathbf{E}$ display slightly lower activity their counterparts D. Beyond this, it was found that cyclohexyl fused pyridine cobalt complexes (B and $\mathbf{C})$ produced the polyethylene with very low molecular weight $\left(0.82 \mathrm{~kg} \mathrm{~mol}^{-1}\right)$ and linear saturated structure. The seven-membered ring fused pyridine(imino)cobalt precatalyst (D and E) produced the higher molecular weight polyethylene $\left(3.2 \mathrm{~kg} \mathrm{~mol}^{-1}\right)$ that contained the vinyl group, which has a significant potential application in the polywax in the package field [6]. The other interesting is the one cycloalkyl fused pyridine (imino) cobalt (B and D) showed better thermal stability (optimum temperature: $50 \sim 60^{\circ} \mathrm{C}$ ) and higher activity $\left(8.65-10.09 \times 10^{6} \mathrm{~g}\right.$ of $\mathrm{PE} \mathrm{mol}^{-1}(\mathrm{Co}) \mathrm{h}^{-1}$ ) than that by double cyclcoalkyl fused bis(imino)pyridine cobalt complexes (C, E, F, and G) (activity: 2.89-5.04 $\times 10^{6} \mathrm{~g}$ of PE $\mathrm{mol}^{-1}(\mathrm{Co}) \mathrm{h}^{-1}$ and optimum temperature at $\left.30-40^{\circ} \mathrm{C}\right)$. Very recently, we have reported a series of $\mathbf{E}$ derivatives that incorporate the cycloalkyl substitution on the ortho position of $\mathrm{N}$-aryl group, which exhibited good activity $\left(2.0 \times 10^{6} \mathrm{~g}\right.$ of $\left.\mathrm{PE} \mathrm{mol}^{-1}(\mathrm{Co}) \mathrm{h}^{-1}\right)$ with the optimum temperature of $30^{\circ} \mathrm{C}$ [43]. Considering the potential positive effect by the cycloalkyl substituent on the ortho position of $\mathrm{N}$-aryl group and the backbone of monocycloheptyl fused pyridine(imino) on the thermal stability and polymerization activity toward ethylene polymerization, therefore, in this work we focused on the mono cycloheptyl-fused bis(imino)pyridine cobalt complexes that incorporated the different ring size of cycloalkyl on the ortho position of $N$-aryl group and their catalytic behavior toward ethylene polymerization in detail.

\section{Results}

\subsection{Synthesis and Characterization of Ligands and Cobalt Complexes Co1-Co6}

According to a literature procedure [49], the condensation reactions of 2-acetyl-5,6,7,8-tetrahydrocycloheptapyridin-9-one with 2-cycloalkylaniline hydrochloride derivatives were conducted in the refluxing $n$-butanol to form the desired $N N N$-pincer ligands ( $\mathbf{L 1} / \mathbf{L 1} \mathbf{1}^{\prime}-\mathbf{L} \mathbf{6} / \mathbf{L 6}^{\prime}$, Chart 1) in moderate isolated yield (32\%-39\%, Scheme 1$)$.

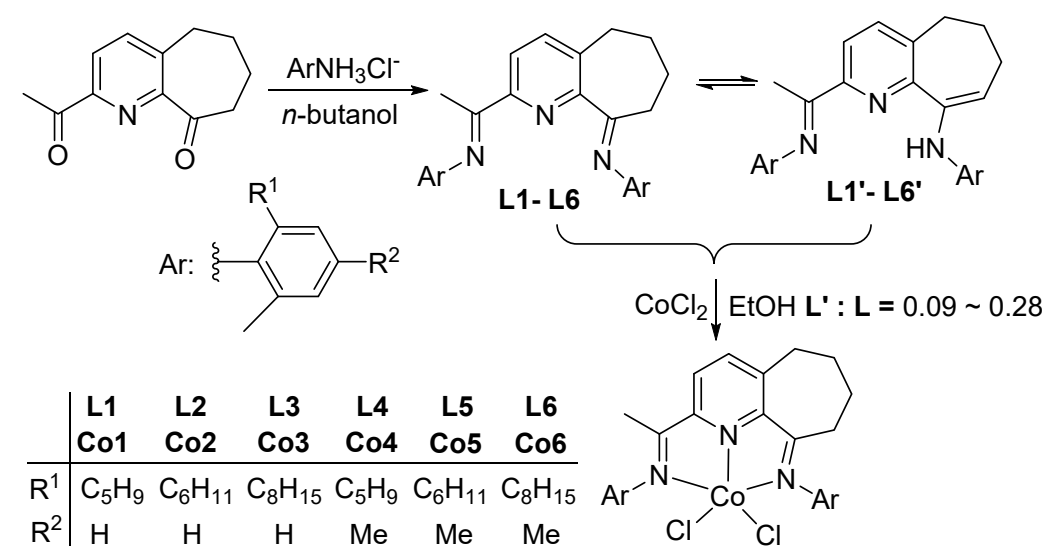

Scheme 1. Synthetic route of ligands L1-L6 and cobalt complexes Co1-Co6.

The ${ }^{1} \mathrm{H}-\mathrm{NMR}$ spectra of the ligands indicated two isomers for each because of the migration of double bond to the imino group linked to the cycloheptane, illustrating major compounds with the remaining imino group $(\mathbf{L})$ instead of double bonds within cycloheptanic derivatives $\left(\mathbf{L}^{\prime}\right.$, minor), 
which is similar to our previous work $[49,50]$. The isomers with $\mathrm{N}-\mathrm{H}$ groups are confirmed with the observation range from 3372 to $3379 \mathrm{~cm}^{-1}$ in their IR spectra, while the isomers containing the $\mathrm{C}=\mathrm{N}$ groups were observed characteristic band around $1644 \mathrm{~cm}^{-1}$. Then using the literature procedure [40,49], the corresponding $N N N$-pincer ligands (L1/L1'-L6/L6) reacted with cobalt(II) dichloride in ethanol to give the corresponding 2-(1-arylimino)ethyl-9-arylimino-5,6,7,8-tetrahydrocyclohepta -pyridine-cobalt(II) chloride complexes, [2-(1-ArN) $\left.\mathrm{C}_{2} \mathrm{H}_{3}-9-\mathrm{ArN}-5,6,7,8-\mathrm{C}_{5} \mathrm{H}_{8} \mathrm{C}_{5} \mathrm{H}_{3} \mathrm{~N}\right] \mathrm{CoCl}_{2},\left(\mathrm{Ar}=2-\left(\mathrm{C}_{5} \mathrm{H}_{9}\right)-6-\mathrm{MeC}_{6} \mathrm{H}_{3}\right.$ Co1, 2- $\left(\mathrm{C}_{6} \mathrm{H}_{11}\right)-6-\mathrm{MeC}_{6} \mathrm{H}_{3} \mathrm{Co}$, 2- $\left(\mathrm{C}_{8} \mathrm{H}_{15}\right)-6-\mathrm{MeC}_{6} \mathrm{H}_{3} \mathrm{Co3}$, 2- $\left(\mathrm{C}_{5} \mathrm{H}_{9}\right)-4,6-\mathrm{Me}_{2} \mathrm{C}_{6} \mathrm{H}_{2}$ Co4, 2- $\left(\mathrm{C}_{6} \mathrm{H}_{11}\right)-4,6-\mathrm{Me}_{2} \mathrm{C}_{6} \mathrm{H}_{2}$ Co5, and 2-( $\left.\mathrm{C}_{8} \mathrm{H}_{15}\right)-4,6-\mathrm{Me}_{2} \mathrm{C}_{6} \mathrm{H}_{2}$ Co6), in high yields (91-96\%). All the ligands L1-L6 have been characterized by FT-IR, ${ }^{1} \mathrm{H} /{ }^{13} \mathrm{C}-\mathrm{NMR}$ spectroscopy and elemental analysis. The cobalt complexes Co1-Co6 have been characterized by IR and elemental analysis and the structure of Co2 and Co3 was confirmed by single-crystal X-ray diffraction. Comparing the IR spectra of free ligands with their corresponding Co complexes, there is no absorption related to the $\mathrm{N}-\mathrm{H}$ groups; moreover, the adsorption around $1644 \mathrm{~cm}^{-1}$ for $v_{\mathrm{C}=\mathrm{N}}$ in ligand compounds is shifted to lower wavenumber around $1609 \mathrm{~cm}^{-1}$ within the cobalt complexes indicating effective coordination of $\mathrm{Co}-\mathrm{N}_{\mathrm{sp} 2}[40,41]$.

\subsection{Single-Crystal X-ray Diffraction Study}

The single-crystals of $\mathbf{C o} 2$ and $\mathrm{Co} 3$ suitable for the X-ray determinations were obtained by slow diffusion of $n$-hexane into their solution in dichloromethane at room temperature. Their molecular structures are shown in Figure 1a,b, and selected bond lengths and angles in Table 1.

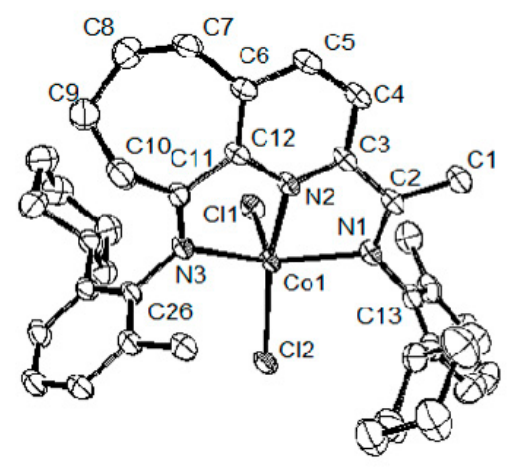

(a)

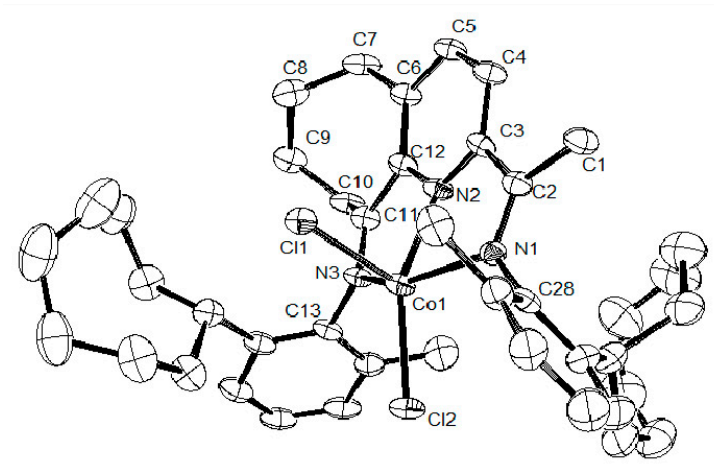

(b)

Figure 1. ORTEP drawing of $\mathbf{C o 2}(\mathbf{a})$ and $\mathbf{C o 3}(\mathbf{b})$ with thermal ellipsoids at the $30 \%$ probability level. Hydrogen atoms are omitted for clarity.

Table 1. Selected bond lengths $(\AA)$ and angles $\left(^{\circ}\right)$ for Co2 and Co3.

\begin{tabular}{ccc|ccc}
\hline \multicolumn{7}{c}{ Co2 } & Co3 & Co2 & Co3 \\
\hline \multicolumn{7}{c}{ Bond Lengths $(\AA)$} \\
$\mathrm{Co}(1)-\mathrm{N}(1)$ & $2.203(4)$ & $2.193(4)$ & $\mathrm{Co}(1)-\mathrm{N}(2)$ & $2.063(4)$ & $2.043(4)$ \\
$\mathrm{Co}(1)-\mathrm{N}(3)$ & $2.182(3)$ & $2.175(4)$ & $\mathrm{Co}(1)-\mathrm{Cl}(1)$ & $2.2922(13)$ & $2.3062(15)$ \\
$\mathrm{Co}(1)-\mathrm{Cl}(2)$ & $2.2646(12)$ & $2.2478(14)$ & $\mathrm{N}(1)-\mathrm{C}(2)$ & $1.286(6)$ & $1.296(6)$ \\
$\mathrm{N}(3)-\mathrm{C}(11)$ & $1.286(5)$ & $1.296(6)$ & & \\
\hline \multicolumn{7}{c}{ Bond Angles (deg) } \\
\hline $\mathrm{N}(1)-\mathrm{Co}(1)-\mathrm{N}(2)$ & $73.80(14)$ & $74.91(16)$ & $\mathrm{N}(1)-\mathrm{Co}(1)-\mathrm{N}(3)$ & $142.70(13)$ & $147.01(15)$ \\
$\mathrm{N}(2)-\mathrm{Co}(1)-\mathrm{N}(3)$ & $74.65(14)$ & $75.80(16)$ & $\mathrm{N}(1)-\mathrm{Co}(1)-\mathrm{Cl}(2)$ & $97.55(11)$ & $98.74(11)$ \\
$\mathrm{N}(2)-\mathrm{Co}(1)-\mathrm{Cl}(2)$ & $152.75(11)$ & $151.03(13)$ & $\mathrm{N}(3)-\mathrm{Co}(1)-\mathrm{Cl}(2)$ & $101.45(10)$ & $99.53(11)$ \\
$\mathrm{N}(1)-\mathrm{Co}(1)-\mathrm{Cl}(1)$ & $100.12(11)$ & $98.37(11)$ & $\mathrm{N}(2)-\mathrm{Co}(1)-\mathrm{Cl}(1)$ & $95.66(11)$ & $89.97(12)$ \\
$\mathrm{N}(3)-\mathrm{Co}(1)-\mathrm{Cl}(1)$ & $102.30(10)$ & $96.45(12)$ & $\mathrm{Cl}(2)-\mathrm{Co}(1)-\mathrm{Cl}(1)$ & $111.42(5)$ & $119.00(6)$ \\
$\mathrm{C}(11)-\mathrm{N}(3)-\mathrm{Co}(1)$ & $116.0(3)$ & $113.9(3)$ & $\mathrm{C}(2)-\mathrm{N}(1)-\mathrm{Co}(1)$ & $114.9(3)$ & $114.8(4)$ \\
\hline
\end{tabular}


Co2 and Co3 have a similar structure and each cobalt was surrounded by two chlorides and three nitrogen atoms belonging to the corresponding NNN-pincer ligand. Both of them possessed distorted square-pyramidal geometry, in which three nitrogen atoms N1, N2, N3 and Cl1 formed the base plane and $\mathrm{Cl} 2$ occupying the apical position. The cobalt atom lies at a distance of $0.505 \AA$ above the basal plane for $\mathrm{Co} 2$ and $0.447 \AA$ for $\mathrm{Co} 3$ in a manner similar to that observed in related $\mathrm{NNNCoCl}_{2}$ counterparts $[40,41,45,47]$. In these two structures, the bond length of Co- $\mathrm{N}_{\text {py }}[2.063(4) \AA$ (Co2), 2.043(1) $\AA$ (Co3)] is significantly shorter than that of Co- $\mathrm{N}_{\text {imine }}[2.203(4)$ and 2.183(3) $\AA$ (Co2), 2.193(4) and 2.175(4) $\AA$ (Co3)], suggesting the stronger donor ability by N-py. At the same time, they are close to that

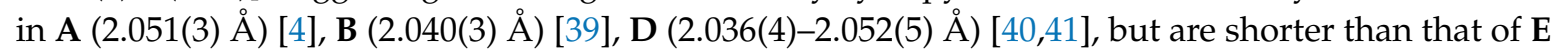
$(2.087(4) \AA)$ [44]. By contrast, the bond length of Co-N $\mathrm{N}_{\text {imine }}[2.175(4)-2.203(4) \AA]$ are longer than that in E (2.128(3) and 2.176(3) $\AA$ ) [51] and $\alpha, \alpha^{\prime}$-bis(arylimino)-2,3:5,6-bis(hexamethylene)pyridine-cobalt(II) complexes (range: 2.1180(18) - 2.1633(18) A) [47], similar to those A [4], B [39], and D [40,41] (range: 2.193-2.320 ̊, Chart 1), highlighting the good chelation properties of $\mathbf{D}$ to the cobalt center. The $N$-aryl rings are almost perpendicular to the coordination plane with dihedral angles of $\left(74.23^{\circ}\right.$ and $\left.78.48^{\circ}\right)$ for $\mathrm{Co} 2$ and $\left(83.84^{\circ}\right.$ and $\left.71.39^{\circ}\right)$ for Co3, respectively. Concurrently, the cyclo-substituents always located in trans-position. The torsion angles for $\mathrm{N}(1)-\mathrm{C}(2)-\mathrm{C}(3)-\mathrm{N}(2)\left[2.09^{\circ}(\mathbf{C o 2}),-7.08^{\circ}(\mathbf{C o 3})\right]$ and $\mathrm{N}(3)-\mathrm{C}(11)-\mathrm{C}(12)-\mathrm{N}(2)\left[-10.57^{\circ}\right.$ (Co2), 13.35 $5^{\circ}$ (Co3) $]$ highlight the deviation from co-planarity between the pyridine ring and the neighboring imine vectors, and the large distinct torsion angles are attributed to the unsymmetrical framework and the different sizes ortho-cycloalkyl substituent [44]. The interesting is the substituents on the ortho position of $\mathrm{N}$-aryl group are always in trans-position.

\subsection{Ethylene Polymerization}

Based on previous findings for structurally related cobalt (II) chloride complexes (e.g., B-E in Chart 1) [39-47], the highest catalytic activity for ethylene polymerization tends to be achieved upon activation with either methylaluminoxane (MAO) or modified methylaluminoxane (MMAO) [6-15]. Therefore, these two co-catalysts were employed to investigate the ethylene polymerization in detail as follows.

\subsubsection{Ethylene Polymerization using Co2/MAO}

With MAO as co-catalyst, Co2 was employed as precatalyst to investigate the ethylene polymerization systematically at various parameters, such as different $\mathrm{Al} / \mathrm{Co}$ molar ratios, reaction temperatures and run times and polymerization results are collected in Table 2.

First of all, with the ethylene pressure set at $10 \mathrm{~atm}$ and the $\mathrm{Al} / \mathrm{Co}$ ratio fixed at 1000, ethylene polymerizations were conducted at a different temperature from 30 to $70{ }^{\circ} \mathrm{C}$ (runs $1-5$, Table 2). The maximum activity of $2.89 \times 10^{6} \mathrm{~g}$ of $\mathrm{PE} \mathrm{mol}{ }^{-1}(\mathrm{Co}) \mathrm{h}^{-1}$ was found at $50{ }^{\circ} \mathrm{C}$ affording a polymeric product; no trace of oligomers could be detected. Further, higher temperature led to the dramatically decreasing of the polymerization activity (Figure 2a). Meanwhile, the molecular weight $\left(M_{\mathrm{w}}\right)$ of the polymer was found to decrease from $22.97 \mathrm{~kg} \mathrm{~mol}^{-1}$ to $6.56 \mathrm{~kg} \mathrm{~mol}^{-1}$ when increasing the temperature from $30^{\circ} \mathrm{C}$ to $70{ }^{\circ} \mathrm{C}$, which can be ascribed to either the more facile chain transfer or chain termination with respect to the chain propagation yielding lower molecular weight PE $[4,40,41,45,51-53]$. Moreover, their GPC curves showed the unimodal distribution and the resultant polyethylene possessed narrow polydispersity $(\mathrm{PDI}=2.0 \sim 3.8)$, which is consistent with the characters of single-site active species [6,39-45].

Fixing the temperature at $50{ }^{\circ} \mathrm{C}$, ethylene polymerizations by $\mathrm{Co} 2 / \mathrm{MAO}$ were conducted at a different $\mathrm{Al} / \mathrm{Co}$ molar ratio from 500 to 3500 (runs 3 and 6-11, Table 2). The highest activity was observed as 3.57 $\times 10^{6} \mathrm{~g}$ of $\mathrm{PE} \mathrm{mol}{ }^{-1}(\mathrm{Co}) \mathrm{h}^{-1}$ with a molar ratio of 2500 (run 9, Table 2), a lower or higher ratio of co-catalyst led to lower activities. The molecular weight of the polymer $\left(M_{\mathrm{W}}\right)$ gradually decreased from $14.2 \mathrm{~kg} \mathrm{~mol}^{-1}$ to $9.39 \mathrm{~kg} \mathrm{~mol}^{-1}$, and the molecular weight distribution kept very narrow (PDI = $2.4-$ 2.7). This result can be ascribed to increased chain transfer to aluminum occurring as a consequence of the larger amounts of alkyl aluminum reagent employed $[4,40,41,44,51,52]$. To our surprise with the $\mathrm{Al} / \mathrm{Co}$ 
molar ratios changing between 3000 and 3500, a dramatic increase of molecular weight was observed and up to $13.96 \mathrm{~kg} \mathrm{~mol}^{-1}$ with 3500 equivalents of MAO (Figure $2 \mathrm{~b}$ ). It would seem plausible that the formation of new active species has been influenced within this molar ratio window, a similar observation has been noted elsewhere $[38,44]$. On the other hand, with regards to the molecular weight distribution, the PDI of polymers are falling in the range from 2.4 to 3.0, slightly broader than their counterparts $\mathbf{D}$ containing symmetric para- $\mathrm{R}^{1}$ groups $(\mathrm{PDI}=2.2)$ [41], this observation was similar to complex E incorporating $\alpha, \alpha^{\prime}$-bis(arylimino)-2,3:5,6-bis(hexamethylene)pyridine containing cycloalkyl ortho-substituents $[43,44]$.

Table 2. Ethylene polymerization results using $\mathrm{Co} 2 / \mathrm{MAO}^{a}$.

\begin{tabular}{|c|c|c|c|c|c|c|c|c|c|}
\hline Run & Precat. & Al/Co & $\mathrm{T}\left({ }^{\circ} \mathrm{C}\right)$ & $t(\min )$ & PE (g) & Act. $b$ & $M_{\mathrm{w}}^{c}$ & $M_{\mathrm{w}} / M_{\mathrm{n}}^{c}$ & $T_{\mathrm{m}}\left({ }^{\circ} \mathrm{C}\right)^{d}$ \\
\hline 1 & $\mathrm{Co} 2$ & 1000 & 30 & 30 & 3.66 & 2.44 & 22.97 & 3.7 & 133.7 \\
\hline 2 & $\mathrm{Co} 2$ & 1000 & 40 & 30 & 3.74 & 2.49 & 17.94 & 3.8 & 131.4 \\
\hline 3 & $\mathrm{Co} 2$ & 1000 & 50 & 30 & 4.33 & 2.89 & 14.21 & 3.0 & 131.1 \\
\hline 4 & $\mathrm{Co} 2$ & 1000 & 60 & 30 & 2.70 & 1.80 & 9.37 & 2.0 & 130.2 \\
\hline 5 & $\mathrm{Co} 2$ & 1000 & 70 & 30 & 1.45 & 0.96 & 6.56 & 2.5 & 130.1 \\
\hline 6 & $\mathrm{Co} 2$ & 500 & 50 & 30 & Trace & - & - & - & - \\
\hline 7 & $\mathrm{Co} 2$ & 1500 & 50 & 30 & 4.37 & 2.91 & 9.76 & 2.4 & 130.3 \\
\hline 8 & $\mathrm{Co} 2$ & 2000 & 50 & 30 & 4.43 & 2.95 & 9.75 & 2.4 & 130.7 \\
\hline 9 & $\mathrm{Co} 2$ & 2500 & 50 & 30 & 5.36 & 3.57 & 9.39 & 2.7 & 130.0 \\
\hline 10 & $\mathrm{Co} 2$ & 3000 & 50 & 30 & 5.10 & 3.40 & 10.67 & 2.6 & 130.5 \\
\hline 11 & $\mathrm{Co} 2$ & 3500 & 50 & 30 & 1.94 & 1.29 & 13.96 & 2.5 & 130.6 \\
\hline 12 & $\mathrm{Co} 2$ & 2500 & 50 & 5 & 2.03 & 8.12 & 10.65 & 2.6 & 130.3 \\
\hline 13 & $\mathrm{Co} 2$ & 2500 & 50 & 15 & 4.70 & 6.26 & 10.34 & 2.5 & 130.7 \\
\hline 14 & $\mathrm{Co} 2$ & 2500 & 50 & 45 & 6.28 & 2.78 & 11.21 & 2.6 & 131.5 \\
\hline 15 & $\mathrm{Co} 2$ & 2500 & 50 & 60 & 7.44 & 2.48 & 11.26 & 2.7 & 130.1 \\
\hline $16^{e}$ & $\mathrm{Co} 2$ & 2500 & 50 & 30 & 4.28 & 2.85 & 13.04 & 2.7 & 130.8 \\
\hline 17 & Co1 & 2500 & 50 & 30 & 6.13 & 4.09 & 10.34 & 2.4 & 130.4 \\
\hline 18 & $\mathrm{Co3}$ & 2500 & 50 & 30 & 4.95 & 3.30 & 20.20 & 3.9 & 132.4 \\
\hline 19 & Co4 & 2500 & 50 & 30 & 5.25 & 3.50 & 13.40 & 2.4 & 131.6 \\
\hline 20 & Co5 & 2500 & 50 & 30 & 4.87 & 3.25 & 9.78 & 2.4 & 130.2 \\
\hline 21 & Co6 & 2500 & 50 & 30 & 4.82 & 3.21 & 25.96 & 4.4 & 132.8 \\
\hline
\end{tabular}

${ }^{a}$ Reaction conditions: $3 \mu \mathrm{mol}$ cobalt complexes, $100 \mathrm{~mL}$ toluene, $10 \mathrm{~atm} \mathrm{C}_{2} \mathrm{H}_{4} ;{ }^{b}$ Values in units of $10^{6} \mathrm{~g}$ of PE mol ${ }^{-1}$ (Co) $\mathrm{h}^{-1} ;{ }^{c}$ Determined using GPC, $M_{\mathrm{W}}: \mathrm{kg} \mathrm{mol}^{-1}{ }^{d}{ }^{d}$ Determined using DSC; ${ }^{e} 5 \mathrm{~atm} \mathrm{C}_{2} \mathrm{H}_{4}$.

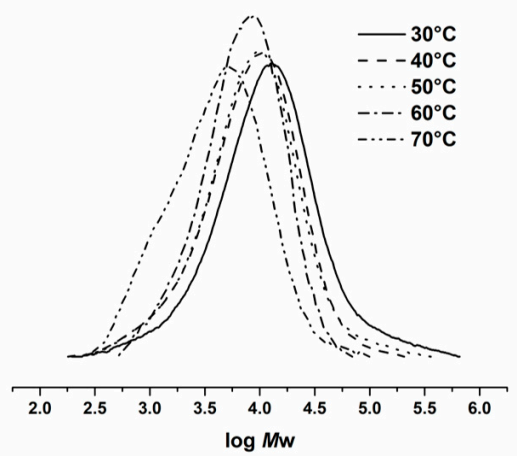

(a)

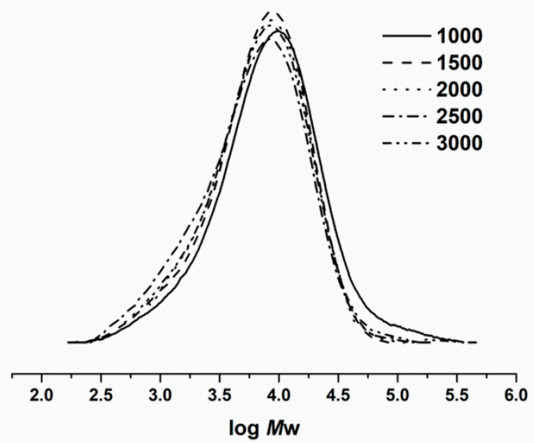

(b)

Figure 2. (a) GPC curves of polyethylene obtained by Co2/MAO at various temperature (runs 1-5, Table 2); (b) GPC curves of polyethylene obtained using Co2/MAO with different molar ratio of $\mathrm{Al} / \mathrm{Co}$ (runs 3 and 6-11, Table 2).

To the end, the lifetime of the Co2/MAO catalyst was probed by conducting the polymerization over $5,15,30,45$ and $60 \mathrm{~min}$ (runs 9 and 12-15, Table 2). Polymerization activity gradually decreased

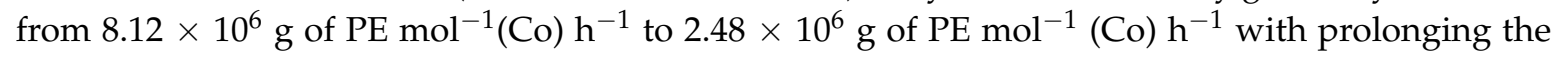


reaction time from, 5 to $60 \mathrm{~min}$, which can be explained by the rapid formation of active species after the addition of MAO and gradual deactivation over extended reaction time [34,40-45]. It is indicated that a short time frame was required to generate all active species, and then the onset of partial deactivation of active species occurred over the course of the reaction [34]. Decreasing ethylene pressure to $5 \mathrm{~atm}$, the polymerization activity $\left(2.85 \times 10^{6} \mathrm{~g}\right.$ of PE mol$\left.{ }^{-1}(\mathrm{Co}) \mathrm{h}^{-1}\right)$ is much lower than that $\left(3.57 \times 10^{6} \mathrm{~g}\right.$ of $\left.\mathrm{PE} \mathrm{mol}^{-1}(\mathrm{Co}) \mathrm{h}^{-1}\right)$ at $10 \mathrm{~atm}$ (runs 9 and 16, Table 2), but the resultant PE polymer possessed much higher molecular weight (13.04 vs. $\left.9.39 \mathrm{~kg} \mathrm{~mol}^{-1}\right)$.

In order to explore the effect imparted by the cycloalkyl ortho-substitution pattern on performance and polymer properties, the other complexes were additionally screened using the optimized reaction conditions established independently for Co2/MAO and the results were collected in Table 2 (runs 17-21). On activation with MAO, all the cobalt complexes Co1-Co6 displayed good activities in the range of 3.21-4.09 $\times 10^{6} \mathrm{~g}$ of $\mathrm{PE} \mathrm{mol}^{-1}(\mathrm{Co}) \mathrm{h}^{-1}$, which fall in the order: $\mathrm{Co1}\left[\mathrm{R}^{1}=\right.$ cyclopentyl] $>$ $\operatorname{Co} 2\left[R^{1}=\right.$ cyclohexyl] $>\operatorname{Co} 3\left[R^{1}=\right.$ cyclooctyl $], \operatorname{Co} 4\left[R^{1}=\right.$ cyclopentyl $]>\operatorname{Co} 5\left[R^{1}=\right.$ cyclohexyl $]>\operatorname{Co} 6$ $\left[\mathrm{R}^{1}=\right.$ cyclooctyl] (Figure 3a). These findings indicate that the size of cycloalkyl group on the ortho position of $\mathrm{N}$-aryl group affects the catalytic activity, in which less bulky cyclopentyl systems gave the higher activities (Co1, Co4) and the bulkiest group of cyclooctyl showed the lowest (Co3, Co6) activities. All the resultant PE by different cobalt complexes Co1-Co6 possessed narrow distribution and PDI value ranged from 2.4 to 3.9, a slightly broader than that found in the D/MAO system. The GPC traces clearly showed unimodal distribution (Figure 3). But the polymer by Co3 and Co6 that bear the bulkiest ortho-substituent of cyclooctyl possessed the highest molecular weight among their analogues, the similar trends were also observed for $\mathbf{E} / \mathrm{MAO}$ system [44]. The para-methyl substituted complexes Co4-Co6 showed slightly lower activity than unsubstituted ones Co1-Co3, which was demonstrated by the activity order: $\operatorname{Co1}\left(R^{2}=H\right)>\operatorname{Co} 4\left(R^{2}=M e\right), \operatorname{Co} 2\left(R^{2}=H\right)>\operatorname{Co} 5\left(R^{2}=M e\right)$ and $\operatorname{Co3}\left(R^{2}=H\right)>\operatorname{Co6}\left(R^{2}=\mathrm{Me}\right)$. However, Figure 3 shows that molecular weights by Co1-Co3 are lower than that by Co4-Co6 respectively. These trends are similar to their analog complex of $\mathbf{B}$ [39].

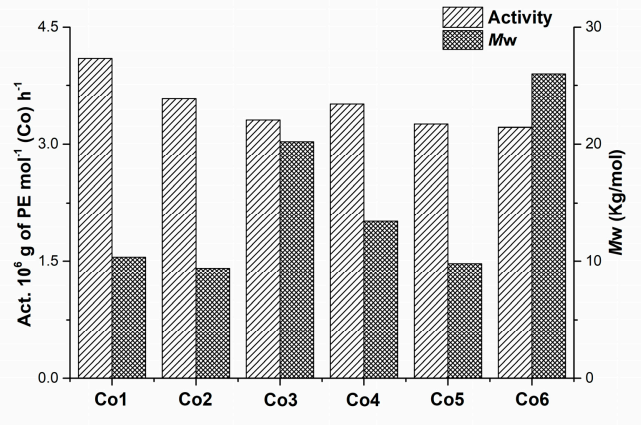

(a)

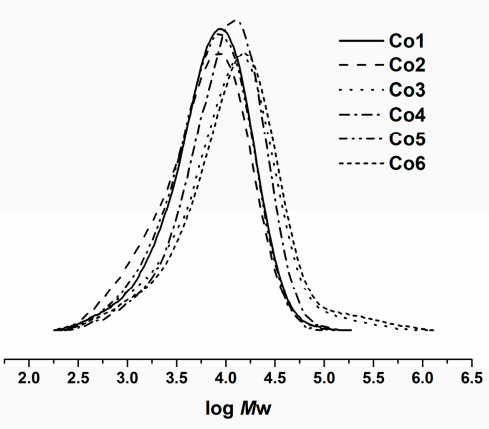

(b)

Figure 3. (a) Polymerization activity and $M_{\mathrm{w}}$ of PE by Co1-Co6/MAO; (b) GPC curves of PE obtained by Co1-Co6/MAO (runs 9 and 17-21, Table 2).

In comparison with previously reported cobalt precatalysts, such as $\mathbf{A}, \mathbf{B}$ and $\mathbf{D}$ (Chart 2) [4,39-41,44], the current systems, Co1-Co6, under comparable polymerization conditions (namely $\mathrm{MAO}$ as co-catalyst, $10 \mathrm{~atm} \mathrm{C}_{2} \mathrm{H}_{4}, 30 \mathrm{~min}$ ) exhibited relatively lower catalytic activity (3.21-4.09 $\times 10^{6} \mathrm{~g}$ of PE $\left.\mathrm{mol}^{-1}(\mathrm{Co}) \mathrm{h}^{-1}\right)$, but are higher than that by precatalyst $\mathrm{E}$ (Chart 2$)$. On the other hand, the resulting polymers by $\mathrm{Co1}-\mathrm{Co} 5 / \mathrm{MAO}$ possessed much higher molecular weight than that found in D/MAO. These findings heights cycloalkyl ortho-substituents in the $\mathrm{N}$-aryl group favored the high molecular weight polymer formation. 

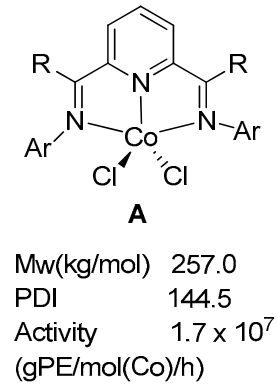

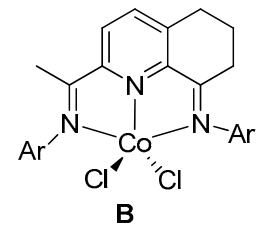

$\mathrm{Mw}(\mathrm{kg} / \mathrm{mol}) 0.910$ PDI $\quad 1.5$ Activity $1.09 \times 10^{7}$ (gPE/mol(Co)/h)

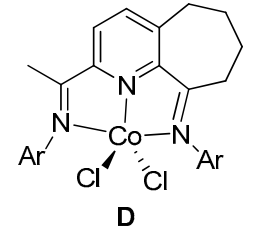

$\mathrm{Mw}(\mathrm{kg} / \mathrm{mol}) 3.20$

PDI $\quad 1.8$

Activity $8.20 \times 10^{6}$

(gPE/mol(Co)/h)

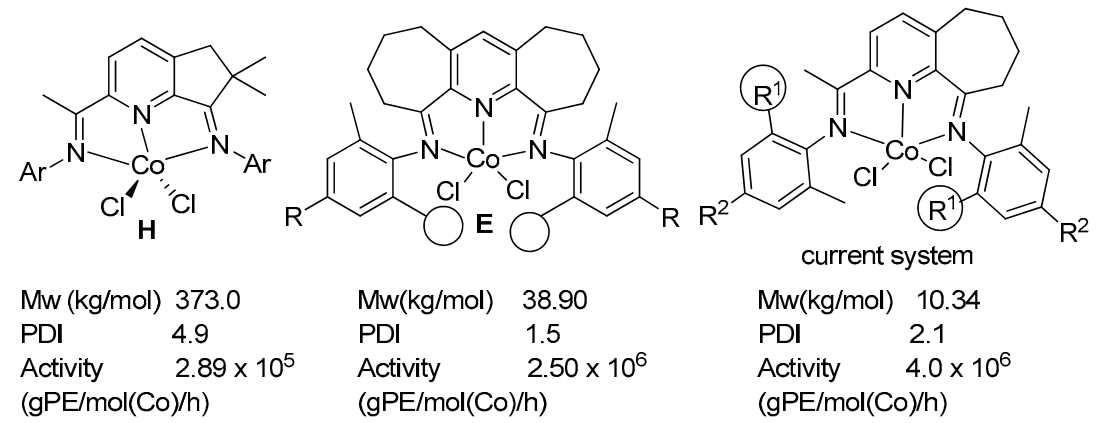

Chart 2. Comparison of the $M_{\mathrm{W}}$, polydispersity (PDI) and polymerization activity of previously reported cobalt precatalysts (A [4], B [39], D [40], E [44] and H [38]) with MAO as activator under related condition.

\subsubsection{Ethylene Polymerization Using Co2/MMAO}

Under the optimized molar ratio for $\mathrm{Co} 2 / \mathrm{MAO}(\mathrm{Al} / \mathrm{Co}=2500)$, ethylene polymerization by $\mathrm{Co2} / \mathrm{MMAO}$ were conducted at various temperatures (from $30^{\circ} \mathrm{C}$ to $60^{\circ} \mathrm{C}$ ) at 10 atm ethylene pressure (runs 1-4, Table 2). The results showed that the highest activity of $2.95 \times 10^{6} \mathrm{~g}$ of PE mol$^{-1}(\mathrm{Co}) \mathrm{h}^{-1}$ was also observed at $50{ }^{\circ} \mathrm{C}$ (run 3, Table 3), similar to the results by Co2/MAO $\left(2.89 \times 10^{6} \mathrm{~g}\right.$ of PE $\left.\mathrm{mol}^{-1}(\mathrm{Co}) \mathrm{h}^{-1}\right)$. Further, higher temperature led to the decrease of activity, indicating the partial decomposition of the active species $[4,40,41,45,51-53]$. The molecular weight of PE decreased from $12.98 \mathrm{~kg} \mathrm{~mol}^{-1}$ to $6.41 \mathrm{~kg} \mathrm{~mol}^{-1}$ with the increasing the temperature from $30^{\circ} \mathrm{C}$ to $60^{\circ} \mathrm{C}$, which can be ascribed to either increased chain transfer to aluminum or chain termination by $\beta$-H elimination at the higher temperature [47-54]. However, all the resultant PE possessed quite narrow distribution $(\mathrm{PDI}=2.5)$ and GPC traces showed unimodal distribution, which is a typical character of a single site catalyst system. A similar observation was also reported for their counterparts $\mathbf{B}, \mathbf{D}$ and $\mathbf{E}$ (Chart 2).

With the temperature fixed at $50{ }^{\circ} \mathrm{C}$, the influence of the $\mathrm{Al} / \mathrm{Co}$ molar ratio was investigated in the range of 1500 to 3000 (runs 3, 5-7, Table 3). A topmost of activity $2.95 \times 10^{6} \mathrm{~g}$ of PE mol${ }^{-1}(\mathrm{Co}) \mathrm{h}^{-1}$ was achieved at the molar ratio of 2500 , which is similar to the results with MAO. As with MMAO, the resultant polyethylenes possessed high molecular weights $\left(8.19-10.22 \mathrm{~kg} \mathrm{~mol}^{-1}\right)$ and narrow polydispersities $\left(M_{\mathrm{W}} / M_{\mathrm{n}} \approx 2.5\right)$, which is consistent with single-site characteristics for the active species [40-45].

In order to investigate the lifetime of the active species, the polymerization tests were conducted over different reaction time from 5, 15, 30 and $60 \mathrm{~min}$ (runs 3 and 8-10, Table 3). The results showed that polymerization activity decreased from 7.04 to $2.07 \times 10^{6} \mathrm{~g}$ of PE $\mathrm{mol}^{-1}(\mathrm{Co}) \mathrm{h}^{-1}$ when increasing the time from 5 to $60 \mathrm{~min}$. As with MMAO system, the molecular weights of the resultant polymer are falling in the range from 8.19 to $10.49 \mathrm{~kg} \mathrm{~mol}^{-1}$, and displaying narrow molecular weight distribution $\left(M_{\mathrm{w}} / M_{\mathrm{n}}=2.4-3.0\right)$. With the ethylene pressure reduced to $5 \mathrm{~atm}$, the activity $\left(1.90 \times 10^{6} \mathrm{~g}\right.$ of PE mol${ }^{-1}$ $(\mathrm{Co}) \mathrm{h}^{-1}$ ) was much lower than that at $10 \mathrm{~atm}$ (run 8, Table 3).

With MMAO as co-catalyst, all the cobalt complexes Co1-Co6 were evaluated for their ethylene

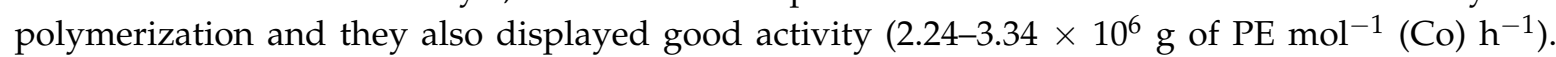
The similar trends in activity and molecular weight as MAO are observed, in which the cyclopentyl 
substituted Co1 and Co4 displayed the highest activity and cyclooctyl substituted cobalt complex (Co3 and Co6) gave the lowest activity, but produced the highest molecular weight polyethylene (runs 3 , 12-16, Table 3). In comparison with D/MMAO, the ortho-cycloalkyl systems in general exhibited more than twice higher molecular weight, although the catalytic activity of D/MMAO is nearly twice as much as that seen for Co1 and Co4, and almost three times that for Co2-Co3 and Co5-Co6. In addition, the molecular weights obtained using Co1-Co6 (range: $8.19-15.94 \mathrm{~kg} \mathrm{~mol}^{-1}$ ) are all significantly higher than that seen for $\mathbf{D} / \mathrm{MMAO}$ system $\left(2.5 \mathrm{~kg} \mathrm{~mol}^{-1}\right)$ [40], which also illustrated the steric effect of the ortho cycloalkyl substituents suppressed the chain transfer and led to the high molecular weight of the polymer. As shown by their GPC curves in Figure 4, the MWD of polymeric products are falling in the range 2.4 to 4.4 .

Table 3. Ethylene polymerization results using $\mathrm{Co2} / \mathrm{MMAO}^{a}$.

\begin{tabular}{|c|c|c|c|c|c|c|c|c|c|}
\hline Run & Precat. & $\mathrm{Al} / \mathrm{Co}$ & $\mathrm{T}\left({ }^{\circ} \mathrm{C}\right)$ & $t(\min )$ & PE (g) & Act. $b$ & $M_{\mathbf{w}}{ }^{c}$ & $M_{\mathrm{w}} / M_{\mathrm{n}}^{c}$ & $T_{\mathrm{m}}\left({ }^{\circ} \mathrm{C}\right)^{d}$ \\
\hline 1 & $\mathrm{Co} 2$ & 2500 & 30 & 30 & 3.34 & 2.23 & 12.98 & 2.8 & 132.5 \\
\hline 2 & $\mathrm{Co} 2$ & 2500 & 40 & 30 & 3.82 & 2.55 & 11.42 & 2.6 & 130.3 \\
\hline 3 & $\mathrm{Co} 2$ & 2500 & 50 & 30 & 4.43 & 2.95 & 8.19 & 2.5 & 129.1 \\
\hline 4 & $\mathrm{Co} 2$ & 2500 & 60 & 30 & 3.20 & 2.13 & 6.41 & 2.5 & 128.1 \\
\hline 5 & $\mathrm{Co} 2$ & 1500 & 50 & 30 & 3.62 & 2.41 & 10.22 & 2.4 & 130.1 \\
\hline 6 & $\mathrm{Co} 2$ & 2000 & 50 & 30 & 3.75 & 2.50 & 9.27 & 2.7 & 129.4 \\
\hline 7 & $\mathrm{Co} 2$ & 3000 & 50 & 30 & 2.27 & 1.51 & 9.86 & 2.3 & 129.9 \\
\hline 8 & $\mathrm{Co} 2$ & 2500 & 50 & 5 & 1.76 & 7.04 & 10.49 & 2.5 & 130.0 \\
\hline 9 & $\mathrm{Co} 2$ & 2500 & 50 & 15 & 3.98 & 5.31 & 8.29 & 2.5 & 129.1 \\
\hline 10 & $\mathrm{Co} 2$ & 2500 & 50 & 60 & 6.21 & 2.07 & 10.06 & 2.4 & 131.2 \\
\hline $11^{e}$ & $\mathrm{Co} 2$ & 2500 & 50 & 30 & 2.85 & 1.90 & 8.90 & 2.5 & 129.9 \\
\hline 12 & Co1 & 2500 & 50 & 30 & 5.01 & 3.34 & 10.01 & 2.4 & 130.0 \\
\hline 13 & $\mathrm{Co} 3$ & 2500 & 50 & 30 & 3.74 & 2.49 & 14.72 & 2.2 & 130.9 \\
\hline 14 & Co4 & 2500 & 50 & 30 & 4.87 & 3.25 & 10.79 & 2.4 & 129.8 \\
\hline 15 & Co5 & 2500 & 50 & 30 & 3.98 & 2.65 & 9.22 & 2.6 & 129.6 \\
\hline 16 & Co6 & 2500 & 50 & 30 & 3.36 & 2.24 & 15.94 & 4.5 & 133.3 \\
\hline
\end{tabular}

${ }^{a}$ Reaction conditions: $3 \mu \mathrm{mol}$ cobalt complexes, $100 \mathrm{~mL}$ toluene, 10 atm $\mathrm{C}_{2} \mathrm{H}_{4} ;{ }^{b}$ Values in units of $10^{6} \mathrm{~g}$ of PE mol ${ }^{-1}$ (Co) $\mathrm{h}^{-1} ;^{c}$ Determined using GPC, $M_{\mathrm{w}}: \mathrm{kg} \mathrm{mol}^{-1}{ }^{d}$ Determined using DSC; ${ }^{e} 5 \mathrm{~atm} \mathrm{C}_{2} \mathrm{H}_{4}$.

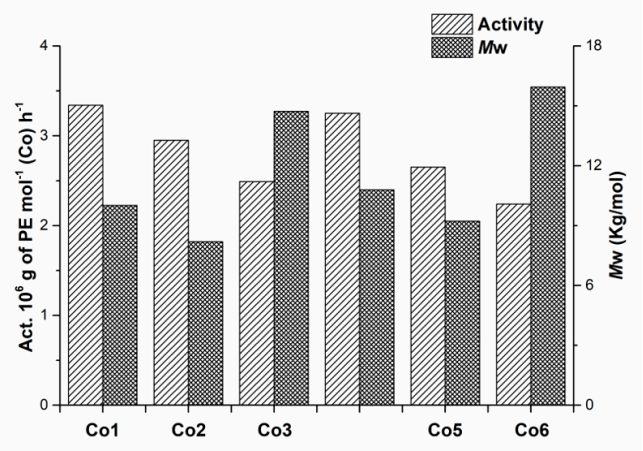

(a)

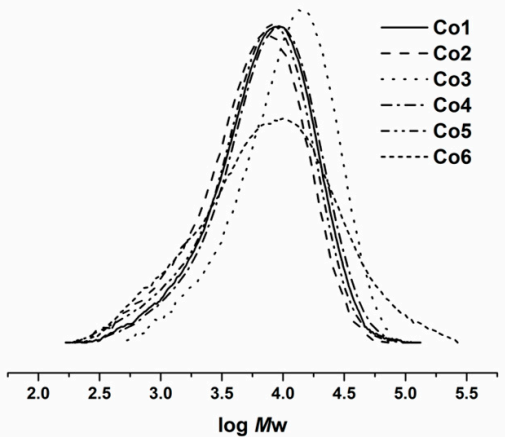

(b)

Figure 4. (a) Polymerization activity and $M_{\mathrm{W}}$ of PE by Co1-Co6/MMAO; (b) GPC curves of PE obtained by Co1-Co6/MMAO (runs 3 and 12-16, Table 3).

\subsection{Characterization of Polyethylene}

Regardless of MMAO or MAO activation, narrow unimodal distributions of the polymers are observed $\left(M_{\mathrm{w}} / M_{\mathrm{n}}=2.2-4.5\right)$ consistent with single-site active species. All the $T_{\mathrm{m}}$ values of the polymer ranging from $129^{\circ} \mathrm{C}$ to $133^{\circ} \mathrm{C}$ [6,40-45]. To provide further support for the linearity of the polymers, representative PE samples using $\mathrm{Co1} / \mathrm{MAO}$ at $50{ }^{\circ} \mathrm{C}$ (run 9, Table 2) were characterized by 
${ }^{1} \mathrm{H} /{ }^{13} \mathrm{C}$-NMR spectroscopy at high temperature (recorded in 1,1,2,2-tetrachloroethane- $d_{2}$ at $120{ }^{\circ} \mathrm{C}$, Figures 5 and 6). The ${ }^{1} \mathrm{H}-\mathrm{NMR}$ spectra clearly showed the weak downfield multiplets at $\delta 5.90$ and $\delta$ 5.00, the typical vinylic signal (Figure 5). While the integration ratio for $\mathrm{H}_{1}: \mathrm{H}_{2} / \mathrm{H}_{2}{ }^{\prime}: \mathrm{H}_{\mathrm{I}}$ is close to 1:2:3, indicating the only the unsaturated chain structure in the PE. The shift 114.38 and 139.54 in ${ }^{13} \mathrm{C}-\mathrm{NMR}$ spectra was ascribed to the unsaturated chain ends $\left(-\mathrm{CH}=\mathrm{CH}_{2}\right)[16,40,41,43,45]$, which agreed well with ${ }^{1} \mathrm{H}-\mathrm{NMR}$ spectra. In addition, the lower intensity peaks at 32.24, 22.92 and 14.22 corresponding to an n-propyl end-group further supported the linear structure of the polyethylene $[16,18,45]$. These findings are further evidenced by their high melting temperature $\left(T_{\mathrm{m}}=130.0^{\circ} \mathrm{C}\right.$, run 9 , Table 2$)$.

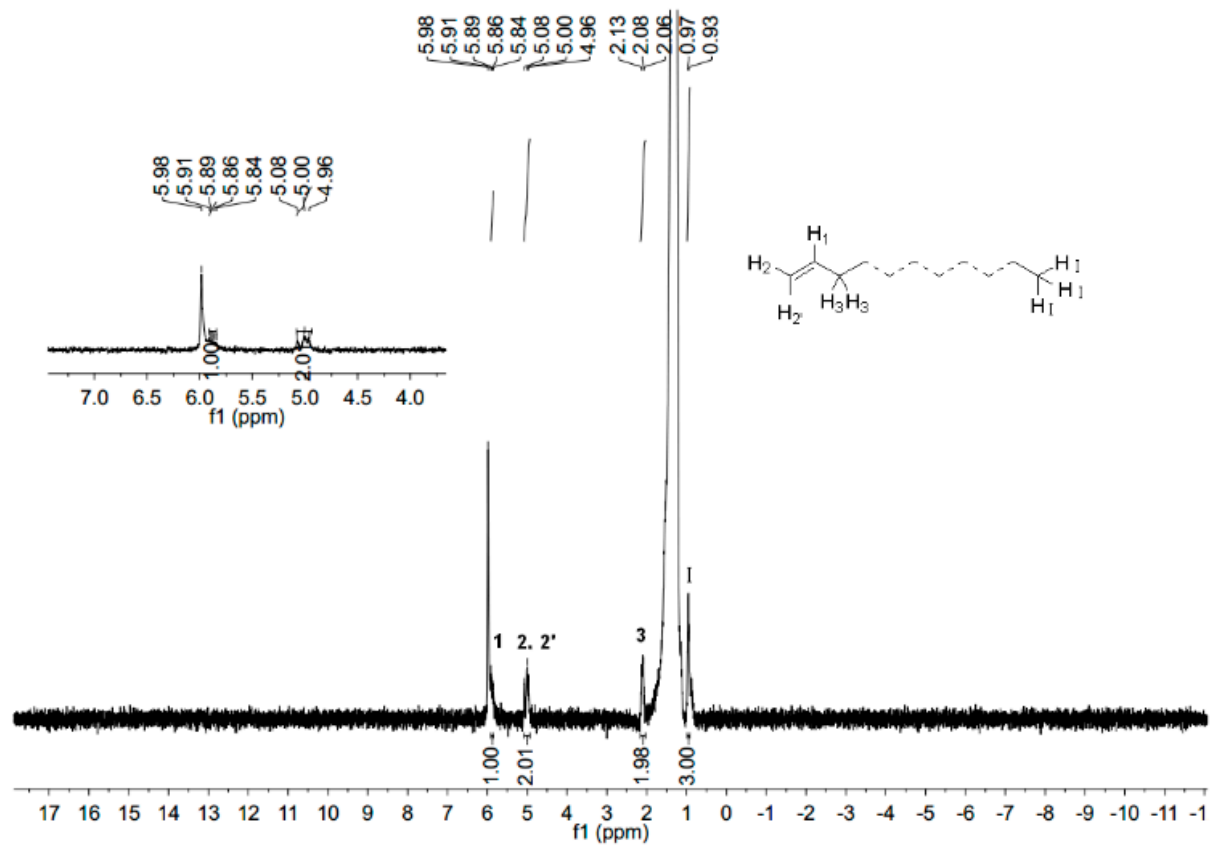

Figure 5. ${ }^{1} \mathrm{H}-\mathrm{NMR}$ spectrum of the polyethylene obtained using $\mathrm{Co2} / \mathrm{MAO}$ at $50{ }^{\circ} \mathrm{C}$ (run 9, Table 2); recorded in 1,1,2,2-tetrachloroethane- $d_{2}$ at $120{ }^{\circ} \mathrm{C}$.

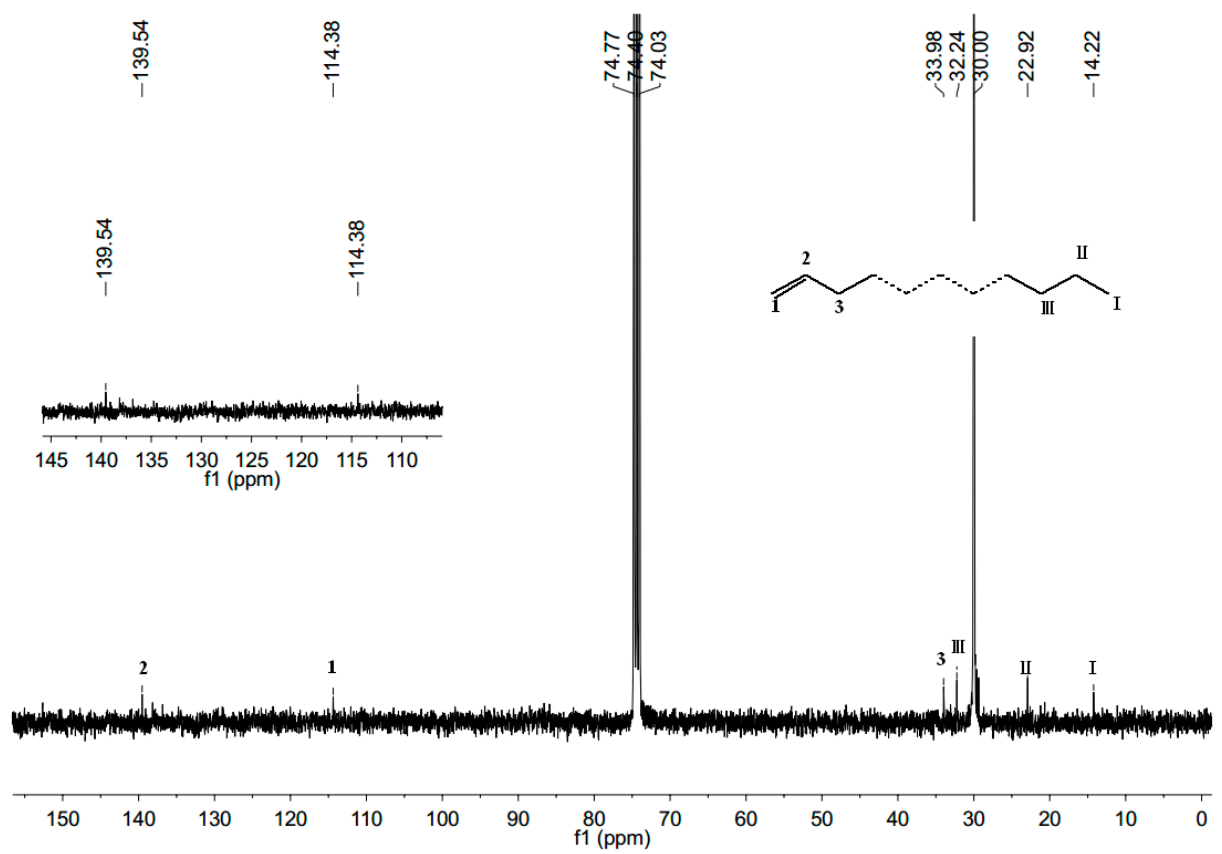

Figure 6. ${ }^{13} \mathrm{C}-\mathrm{NMR}$ spectrum of the polyethylene obtained using $\mathrm{Co2} / \mathrm{MAO}$ at $50{ }^{\circ} \mathrm{C}$ (run 9, Table 2); recorded in 1,1,2,2-tetrachloroethane- $d_{2}$ at $120^{\circ} \mathrm{C}$. 
The resultant PE by Co2/MMAO were also characterized by ${ }^{1} \mathrm{H} /{ }^{13} \mathrm{C}-\mathrm{NMR}$ spectra, and shown in Figures 7 and 8. The ${ }^{1} \mathrm{H}-\mathrm{NMR}$ spectrum also showed the signal of a vinyl group $(\delta 5.90$ and $\delta$ $5.00)$, which was also confirmed by the signal in ${ }^{13} \mathrm{C}-\mathrm{NMR}(\delta 139.55,114.40)$. However, the integration ratio for $\mathrm{H}_{1}: \mathrm{H}_{2} / \mathrm{H}_{2}{ }^{\prime}: \mathrm{H}_{\mathrm{I}}$ is close to 1:2:5 (Figure 7), dissimilar to that seen with MAO at the same temperature, which suggested both the saturated and unsaturated chain structure in polyethylene. Moreover, the signal of the lower intensity peaks at 32.24, 22.93 and 14.26 in ${ }^{13} \mathrm{C}-\mathrm{NMR}$ corresponds to $n$-propyl end-group, indicating the linear structure of PE. These observations would suggest that, chain termination via $\beta-\mathrm{H}$ elimination in Co2/MMAO system is no longer the sole chain transfer pathway operative, with chain transfer to aluminum now competitive $[16,18,44]$.

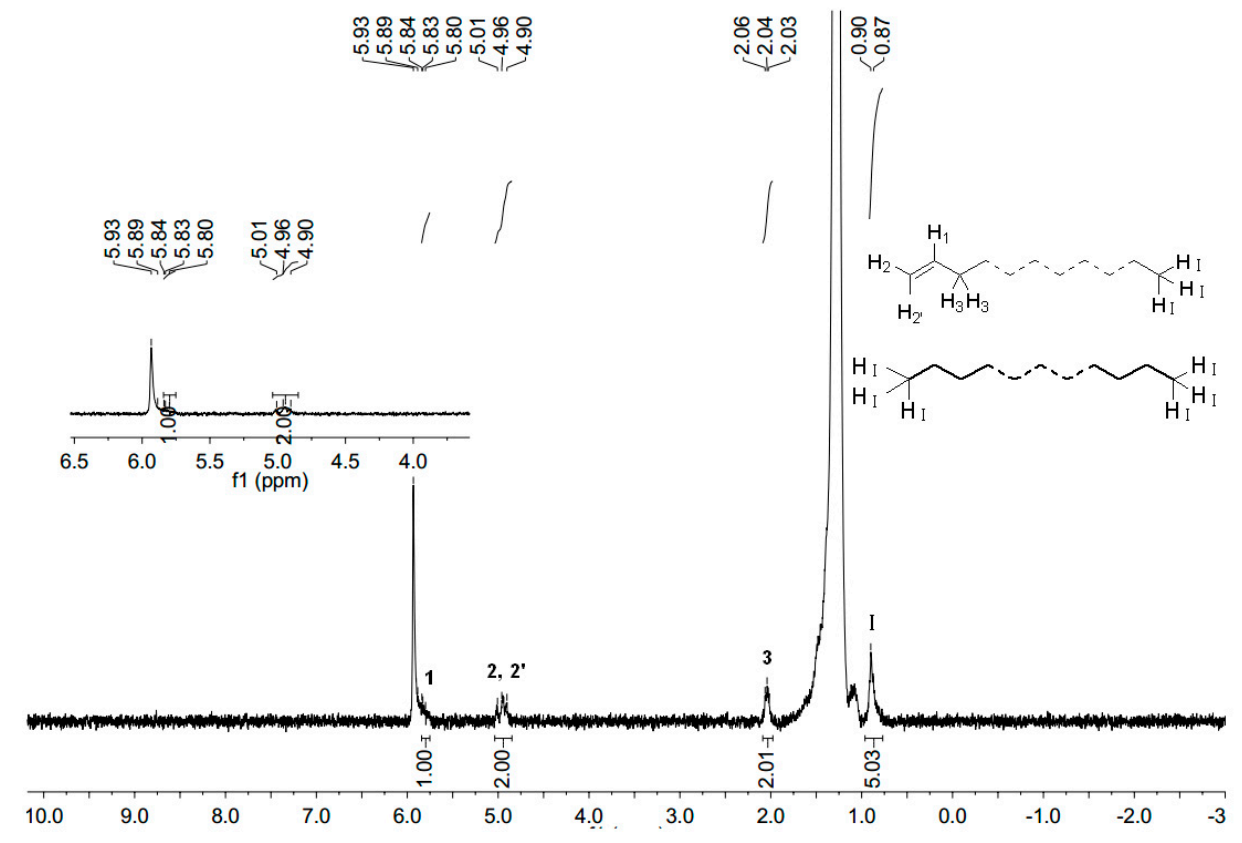

Figure 7. ${ }^{1} \mathrm{H}-\mathrm{NMR}$ spectrum of the polyethylene obtained using $\mathrm{Co2} / \mathrm{MMAO}$ at $50{ }^{\circ} \mathrm{C}$ (run 3, Table 3); recorded in 1,1,2,2-tetrachloroethane- $d_{2}$ at $120^{\circ} \mathrm{C}$.

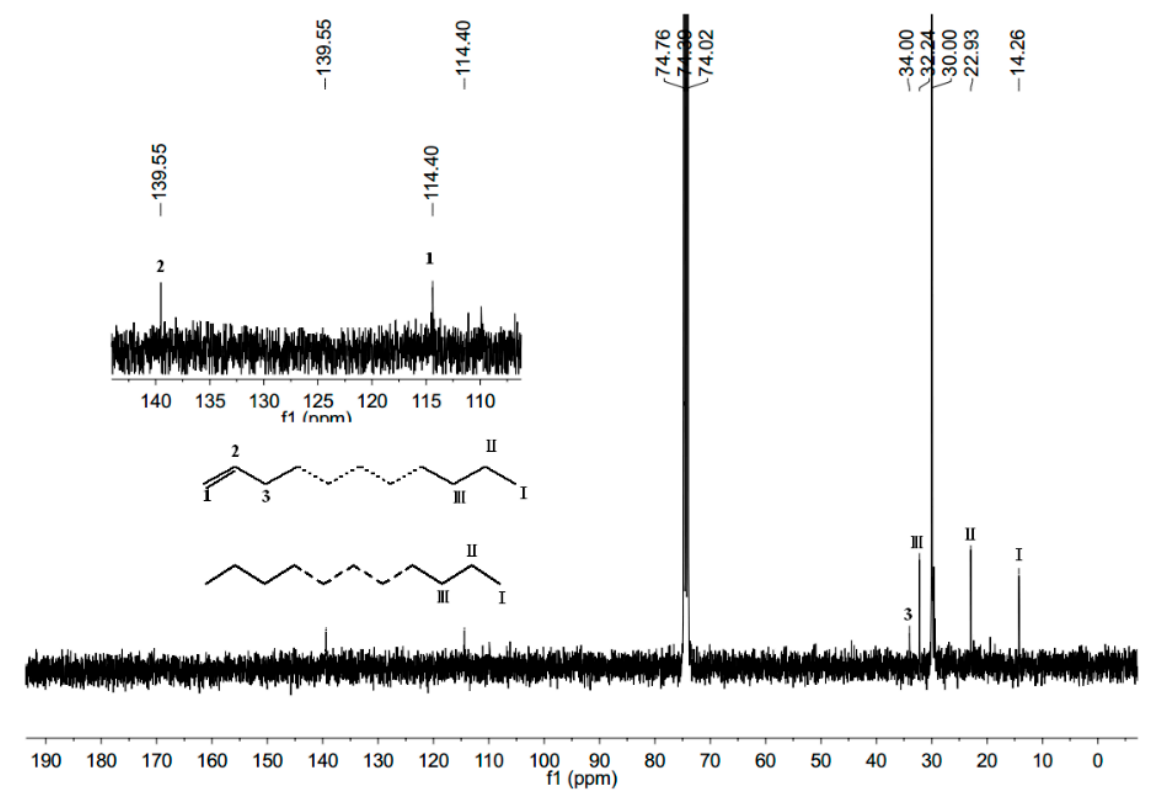

Figure 8. ${ }^{13} \mathrm{C}-\mathrm{NMR}$ spectrum of the polyethylene obtained using $\mathrm{Co} 2 / \mathrm{MMAO}$ at $50{ }^{\circ} \mathrm{C}$ (run 3, Table 3); recorded in 1,1,2,2-tetrachloroethane- $d_{2}$ at $120^{\circ} \mathrm{C}$. 


\section{Materials and Methods}

\subsection{General Considerations}

All the synthetic procedures for air/moisture-sensitive compounds were performed under a nitrogen atmosphere with standard Schlenk techniques. Toluene as a solvent for polymerization was refluxed over sodium (a small amount of benzophenone) and distilled under nitrogen prior to use. Methylaluminoxane (MAO, 1.46 M solution in toluene) and modified methylaluminoxane (MMAO, $1.93 \mathrm{M}$ in $n$-heptane) were bought from Akzo Nobel Corp (Nanjing, China). High-purity ethylene was bought from Beijing Yanshan Petrochemical company (Beijing, China) and used as received. NMR spectra were recorded using a Bruker DMX $400 \mathrm{MHz}$ instrument (Beijing, China) at ambient temperature using TMS as an internal standard. FT-IR spectra were recorded using a Perkin-Elmer System 2000 FT-IR spectrometer (Shanghai, China). Elemental analysis was carried out using a Flash EA1112 microanalyzer (Beijing, China). Molecular weights and molecular weight distribution of polyethylenes were determined using a PL-GPC220 GPC/SEC High Temperature System (Beijing, China). Data collection and handling were carried out using Cirrus GPC Software (Beijing, China) and Multi Detector Software (Beijing, China). The calibrants for constructing conventional calibration is Polystyrene Calibration KitS-M-10 from PL Company (Beijing, China). The true average molecular weights of PE are transferred by inputting the $M-H$ constants of PE. K of 0.727 and $\alpha$ of 40.6 are provided by PL Company (Beijing, China). Samples were dissolved at a concentration of 1.0 to $2.5 \mathrm{mg} \mathrm{mL}^{-1}$, depending on the molecular weights. DSC trace and melting points of polyethylene were obtained from the second scanning run on DSCQ2000 at a heating rate of $10{ }^{\circ} \mathrm{C} \mathrm{min}{ }^{-1}$ from $-20{ }^{\circ} \mathrm{C}$ to $200{ }^{\circ} \mathrm{C}$. ${ }^{1} \mathrm{H} /{ }^{13} \mathrm{C}-\mathrm{NMR}$ spectra of the polyethylene were recorded using a Bruker DMX $300 \mathrm{MHz}$ instrument (Beijing, China) at $120{ }^{\circ} \mathrm{C}$ in deuterated 1,1,2,2-tetrachloroethane with TMS as an internal standard. The compound of 2-acetyl-5,6,7,8-tetrahydrocycloheptapyridin-9-one was synthesized according to the literature [49] and the 2-cycloalkylaniline hydrochlorides were prepared using literature methods [34].

\subsection{Synthesis of 2-(1-ArN) $\mathrm{C}_{2} \mathrm{H}_{3}-9-\mathrm{ArN}-5,6,7,8-\mathrm{C}_{5} \mathrm{H}_{8} \mathrm{C}_{5} \mathrm{H}_{3} \mathrm{~N}$ (L1-L6)}

$\mathrm{Ar}=2-\left(\mathrm{C}_{5} \mathrm{H}_{9}\right)-6-\mathrm{MeC}_{6} \mathrm{H}_{3}\left(\mathbf{L 1} / \mathbf{L} \mathbf{1}^{\prime}\right) . \quad$ 2-cyclopentyl-6-methylphenylamine hydrochloride $(0.46 \mathrm{~g}$, $2.2 \mathrm{mmol})$ was added to a solution of $(0.20 \mathrm{~g}, 1.0 \mathrm{mmol})$ 2-acetyl-5,6,7,8-tetrahydrocycloheptapyridin9-one with $p$-toluenesulfonic acid $(20.0 \mathrm{mg}$ ) as catalyst in $30 \mathrm{~mL}$ of $n$-butanol. The mixture was stirred at reflux temperature for $6 \mathrm{~h}$. The solvent was then evaporated at reduced pressure, and the residue was purified by alumina column chromatography with petroleum ether/dichloromethane/triethylamine $[100 / 1 / 1, v / v / v]$ to afford $\mathbf{L 1}(0.19 \mathrm{~g}, 38.1 \%)$ as a yellow oil with molar ratio of $\mathbf{L 1} / \mathbf{L 1}{ }^{\prime}=1 / 0.12$ (detected by $\left.{ }^{1} \mathrm{H}-\mathrm{NMR}\right) .{ }^{1} \mathrm{H}-\mathrm{NMR}\left(\mathrm{CDCl}_{3}, 400 \mathrm{MHz}, \mathrm{TMS}\right): \delta 8.39\left(\mathrm{t}, J=7.1 \mathrm{~Hz}, 1 \mathrm{H}, \mathbf{L 1}-H_{\mathrm{Py}}\right), 8.25$ (d, $\left.\left.J=8.2 \mathrm{~Hz}, 1 \mathrm{H}, \mathbf{L 1}^{\prime}-H_{\mathrm{Py}}\right), 7.68\left(\mathrm{~d}, J=7.8 \mathrm{~Hz}, 1 \mathrm{H}, \mathbf{L 1}^{\prime}-H_{\mathrm{Py}}\right), 7.62\left(\mathrm{~d}, J=8.0 \mathrm{~Hz}, 1 \mathrm{H}, \mathbf{L} 1-H_{\mathrm{Py}}\right), \mathrm{H}\right), 7.18(\mathrm{t}$, $\left.J=8.5 \mathrm{~Hz}, 2 \mathrm{H}, 2 \times \mathbf{L} 1-H_{\mathrm{Ar}}\right), 7.11\left(\mathrm{t}, J=5.8 \mathrm{~Hz}, 2 \mathrm{H}, 2 \times \mathbf{L 1}^{\prime}-H_{\mathrm{Ar}}\right), 7.04\left(\mathrm{t}, J=6.8 \mathrm{~Hz}, 2 \mathrm{H}, 2 \times \mathbf{L} 1-H_{\mathrm{Ar}}\right.$ and $\left.2 \times \mathbf{L 1}^{\prime}-H_{\mathrm{Ar}}\right), 6.99\left(\mathrm{~d}, J=7.3 \mathrm{~Hz}, 2 \mathrm{H}, 2 \times \mathbf{L} 1-H_{\mathrm{Ar}}\right), 6.85\left(\mathrm{~d}, J=7.0 \mathrm{~Hz}, 2 \mathrm{H}, 2 \times \mathbf{L 1}^{\prime}-H_{\mathrm{Ar}}\right), 6.46$ $\left(\mathrm{s}, 1 \mathrm{H}, \mathbf{L} 1^{\prime}-H_{\mathrm{NH}}\right), 4.66\left(\mathrm{t}, J=6.9 \mathrm{~Hz}, 1 \mathrm{H}, \mathbf{L 1}^{\prime}-\mathrm{H}_{\mathrm{CH}=}\right), 3.03-2.91\left(\mathrm{~m}, 2 \mathrm{H}, \mathbf{L 1}-H_{\mathrm{CH} 2}\right), 2.90-2.81(\mathrm{~m}, 2 \mathrm{H}$, L1- $\left.H_{\mathrm{CH} 2}\right), 2.77\left(\mathrm{t}, J=6.3 \mathrm{~Hz}, 2 \mathrm{H}, \mathbf{L 1}^{\prime}-H_{\mathrm{CH} 2}\right), 2.37\left(\mathrm{~s}, 3 \mathrm{H}, \mathbf{L 1}^{\prime}-H_{\mathrm{CH} 3}\right), 2.34\left(\mathrm{t}, J=6.1 \mathrm{~Hz}, 2 \mathrm{H}, \mathbf{L 1}-H_{\mathrm{CH} 2}\right)$, $2.26\left(\mathrm{~s}, 2 \mathrm{H}, \mathbf{L 1}-\mathrm{H}_{\mathrm{CH} 2}\right), 2.21\left(\mathrm{~s}, 3 \mathrm{H}, \mathbf{L 1}-H_{\mathrm{CH} 3}\right), 2.01\left(\mathrm{~d}, J=6.2 \mathrm{~Hz}, 6 \mathrm{H}, 2 \times \mathbf{L 1}-H_{\mathrm{PhCH} 3}\right), 1.95-1.88(\mathrm{~m}$, $\left.2 \mathrm{H}, 2 \times \mathbf{L} 1-H_{\mathrm{CH} 2}\right), 1.82\left(\mathrm{~s}, 4 \mathrm{H}, \mathbf{L} 1-H_{\mathrm{CH} 2}\right), 1.72\left(\mathrm{t}, J=5.7 \mathrm{~Hz}, 4 \mathrm{H}, \mathbf{L 1}-H_{\mathrm{CH} 2}\right), 1.60(\mathrm{~d}, J=5.3 \mathrm{~Hz}, 4 \mathrm{H}$, L1- $\left.\mathrm{CH}_{\mathrm{CH}}\right), 1.54\left(\mathrm{~s}, 4 \mathrm{H}, \mathbf{L 1}-\mathrm{H}_{\mathrm{CH} 2}\right) .{ }^{13} \mathrm{C}-\mathrm{NMR}\left(\mathrm{CDCl}_{3}, 100 \mathrm{MHz}, \mathrm{TMS}\right): \delta 173.7,167.5,156.6,155.0,148.1$, 137.4, 135.9, 134.4, 134.0, 128.1, 127.9, 125.5, 125.3 125.1, 124.1, 124.0,123.9, 123.5, 123.3, 121.6, 40.6, 40.5, $34.2,34.1,33.9,33.7,32.4,31.9,27.2,26.3,26.0,25.9,25.8,24.1,22.9,18.5,17.0,16.9$. FTIR $\left(\mathrm{KBr}_{\mathrm{cm}}{ }^{-1}\right)$ : $3372\left(v_{\mathrm{N}-\mathrm{H}}, \mathrm{w}\right), 2946(\mathrm{~s}), 2864(\mathrm{~m}), 1642\left(v_{\mathrm{C}=\mathrm{N}}, \mathrm{m}\right), 1564(\mathrm{w}), 1455(\mathrm{~s}), 1359(\mathrm{~m}), 1302(\mathrm{w}), 1261(\mathrm{~m}), 1192$ $(\mathrm{m}), 1164(\mathrm{w}), 1118(\mathrm{w}), 1088(\mathrm{~m}), 1032(\mathrm{w}), 848(\mathrm{w}), 805(\mathrm{w}), 746(\mathrm{~s})$. Anal. Calcd for $\mathrm{C}_{36} \mathrm{H}_{43} \mathrm{~N}_{3}$ : C, 83.51, H, 8.37, N, 8.12; Found: C, 83.18, H, 8.61, N, 8.43\%. 
$\mathrm{Ar}=2-\left(\mathrm{C}_{6} \mathrm{H}_{11}\right)-6-\mathrm{MeC}_{6} \mathrm{H}_{3}\left(\mathbf{L} 2 / \mathbf{L} 2^{\prime}\right)$. Using a similar procedure and molar ratios to that described for $\mathbf{L 1} / \mathbf{L 1}^{\prime}$ but with 2-cyclohexyl-6-methylphenylamine hydrochloride as the amine, $\mathbf{L 2}$ / $\mathbf{L 2}{ }^{\prime}{ }^{\prime}$ was obtained as a yellow oil $\left(0.22 \mathrm{~g}, 39.7 \%\right.$ ) with molar ratio of $\mathbf{L} 2 / \mathbf{L} 2^{\prime}=1 / 0.11$ (detected by $\left.{ }^{1} \mathrm{H}-\mathrm{NMR}\right) .{ }^{1} \mathrm{H}-\mathrm{NMR}\left(\mathrm{CDCl}_{3}\right.$, $400 \mathrm{MHz}, \mathrm{TMS}): \delta 8.38\left(\mathrm{t}, J=8.5 \mathrm{~Hz}, 1 \mathrm{H}, \mathbf{L} 2-H_{\mathrm{Py}}\right), 8.24\left(\mathrm{~d}, J=7.8 \mathrm{~Hz}, 1 \mathrm{H}, \mathbf{L 2}^{\prime}-H_{\mathrm{Py}}\right), 7.68(\mathrm{~d}, J=7.7 \mathrm{~Hz}$, $\left.\left.1 \mathrm{H}, \mathbf{L 2}^{\prime}-H_{\mathrm{Py}}\right), 7.63\left(\mathrm{~d}, J=7.6 \mathrm{~Hz}, 1 \mathrm{H}, \mathbf{L} 2-H_{\mathrm{Py}}\right), \mathrm{H}\right), 7.14\left(\mathrm{t}, J=8.1 \mathrm{~Hz}, 2 \mathrm{H}, 2 \times \mathbf{L} 2-H_{\mathrm{Ar}}\right.$ and $\left.2 \times \mathbf{L 2}^{\prime}-H_{\mathrm{Ar}}\right)$, $7.05\left(\mathrm{~m}, 2 \mathrm{H}, 2 \times \mathbf{L} 2-H_{\mathrm{Ar}}\right.$ and $\left.2 \times \mathbf{L} 2^{\prime}-H_{\mathrm{Ar}}\right), 6.99\left(\mathrm{~d}, J=7.3 \mathrm{~Hz}, 2 \mathrm{H}, 2 \times \mathbf{L} 2-H_{\mathrm{Ar}}\right), 6.94\left(\mathrm{~s}, 2 \mathrm{H}, 2 \times \mathbf{L 2}^{\prime}-H_{\mathrm{Ar}}\right)$, $6.41\left(\mathrm{~s}, 1 \mathrm{H}, \mathbf{L} 2{ }^{\prime}-H_{\mathrm{NH}-}\right), 4.66\left(\mathrm{t}, J=6.9 \mathrm{~Hz}, 1 \mathrm{H}, \mathbf{L 2}^{\prime}-\mathrm{H}_{\mathrm{CH}=}\right), 2.96\left(\mathrm{t}, J=6.0 \mathrm{~Hz}, 2 \mathrm{H}, \mathbf{L} 2-H_{\mathrm{CH} 2}\right), 2.79-2.71(\mathrm{~m}$, $\left.2 \mathrm{H}, \mathbf{L} 2-H_{\mathrm{CH} 2}\right), 2.64\left(\mathrm{~s}, 2 \mathrm{H}, \mathbf{L 2}{ }^{\prime}-H_{\mathrm{CH} 2}\right), 2.38\left(\mathrm{~s}, 3 \mathrm{H}, \mathbf{L 2}{ }^{\prime}-H_{\mathrm{CH} 3}\right), 2.34\left(\mathrm{t}, J=6.3 \mathrm{~Hz}, 2 \mathrm{H}, \mathbf{L} 2-H_{\mathrm{CH} 2}\right), 2.28$ (s, $\left.2 \mathrm{H}, \mathbf{L} 2-H_{\mathrm{CH} 2}\right), 2.21\left(\mathrm{~s}, 3 \mathrm{H}, \mathbf{L} 2-H_{\mathrm{CH} 3}\right), 2.01\left(\mathrm{~d}, J=5.0 \mathrm{~Hz}, 6 \mathrm{H}, 2 \times \mathbf{L}_{2}-H_{\mathrm{CH} 3-\mathrm{Ph}}\right), 1.97\left(\mathrm{~s}, 2 \mathrm{H}, 2 \times \mathbf{L}_{2}-H_{\mathrm{CH} 2}\right)$, 1.91-1.82 (m, 4H, L2- $\left.\mathrm{H}_{\mathrm{CH} 2}\right), 1.78-1.67\left(\mathrm{~m}, 8 \mathrm{H}, 2 \times \mathbf{L} 2-\mathrm{H}_{\mathrm{CH} 2}\right), 1.53\left(\mathrm{~s}, 8 \mathrm{H}, 2 \times \mathbf{L} 2-\mathrm{H}_{\mathrm{CH} 2}\right) .{ }^{13} \mathrm{C}-\mathrm{NMR}\left(\mathrm{CDCl}_{3}\right.$, $100 \mathrm{MHz}$, TMS): $\delta$ 173.9, 167.5, 156.7, 155.1, 148.1, 137.5, 146.4, 138.2, 137.5, 135.9, 135.8, 135.4, 128.1, 128.0, 124.4, 124.0, 123.5, 123.4, 39.2, 38.8, 34.1, 33.6, 33.5, 33.2, 32.4, 31.2, 27.5, 27.3, 26.6, 26.3, 24.1, 18.6, 17.1. FT-IR $\left(\mathrm{KBr}, \mathrm{cm}^{-1}\right): 3379\left(v_{\mathrm{N}-\mathrm{H}}, \mathrm{w}\right), 2951(\mathrm{~s}), 2866(\mathrm{~m}), 1644\left(v_{\mathrm{C}=\mathrm{N}}, \mathrm{m}\right), 1564(\mathrm{w}), 1457(\mathrm{~s}), 1362(\mathrm{~m}), 1303(\mathrm{w}), 1268$ (m), $1195(\mathrm{~m}), 1164(\mathrm{w}), 1121(\mathrm{w}), 1088(\mathrm{~m}), 1033(\mathrm{w}), 850(\mathrm{w}), 805(\mathrm{w}), 747(\mathrm{~s})$. Anal. Calcd for $\mathrm{C}_{38} \mathrm{H}_{47} \mathrm{~N}_{3}: \mathrm{C}$, 83.62, H, 8.68, N, 7.70; Found: C, 83.89, H, 8.31, N, 8.07.

$\mathrm{Ar}=2-\left(\mathrm{C}_{8} \mathrm{H}_{15}\right)-6-\mathrm{MeC}_{6} \mathrm{H}_{3}\left(\mathbf{L} 3 / \mathbf{L 3}^{\prime}\right)$. Using a similar procedure and molar ratios to that described for $\mathbf{L 1} / \mathbf{L 1}^{\prime}$, but with 2-cyclooctyl-6-methylphenylamine hydrochloride as the amine, $\mathbf{L 3} / \mathbf{L 3}^{\prime}$ was obtained as a yellow powder $(0.21 \mathrm{~g}, 34.5 \%)$ with molar ratio of $\mathbf{L 3} / \mathbf{L 3}^{\prime}=1 / 0.28$ (detected by ${ }^{1} \mathrm{H}-\mathrm{NMR}$ ). ${ }^{1} \mathrm{H}-\mathrm{NMR}$ $\left(\mathrm{CDCl}_{3}, 400 \mathrm{MHz}, \mathrm{TMS}\right): \delta 8.38\left(\mathrm{~m}, 1 \mathrm{H}, \mathrm{L} 3-H_{\mathrm{Py}}\right), 8.24\left(\mathrm{~d}, J=7.6 \mathrm{~Hz}, 1 \mathrm{H}, \mathrm{L3}^{\prime}-H_{\mathrm{Py}}\right), 7.68(\mathrm{~d}, J=7.3 \mathrm{~Hz}, 1 \mathrm{H}$, $\left.\mathbf{L 3}^{\prime}-H_{\mathrm{Py}}\right), 7.63\left(\mathrm{~d}, J=8.0 \mathrm{~Hz}, 1 \mathrm{H}, \mathbf{L} 3-H_{\mathrm{Py}}\right), 7.12\left(\mathrm{t}, J=5.1 \mathrm{~Hz}, 2 \mathrm{H}, 2 \times \mathbf{L}^{2}-H_{\mathrm{Ar}}\right.$ and $\left.2 \times \mathbf{L 3}^{\prime}-H_{\mathrm{Ar}}\right), 7.05-6.96$ $\left(\mathrm{m}, 2 \mathrm{H}, 2 \times \mathbf{L} 3-H_{\mathrm{Ar}}\right.$ and $\left.2 \times \mathbf{L}^{\prime}-H_{\mathrm{Ar}}\right), 6.92\left(\mathrm{~d}, J=7.4 \mathrm{~Hz}, 2 \mathrm{H}, 2 \times \mathbf{L} 3-H_{\mathrm{Ar}}\right.$ and $\left.2 \times \mathrm{L}^{\prime}-H_{\mathrm{Ar}}\right), 6.35(\mathrm{~s}, 1 \mathrm{H}$, $\left.\mathbf{L 3}^{\prime}-H_{\mathrm{NH}}\right), 4.64\left(\mathrm{t}, J=6.5 \mathrm{~Hz}, 1 \mathrm{H}, \mathbf{L 3}^{\prime}-H_{\mathrm{CH}}\right), 2.99-2.93\left(\mathrm{~m}, 2 \mathrm{H}, \mathbf{L} 3-H_{\mathrm{CH} 2}\right), 2.78-2.74\left(\mathrm{~m}, 2 \mathrm{H}, \mathbf{L} 3-H_{\mathrm{CH} 2}\right), 2.38$ $\left(\mathrm{s}, 3 \mathrm{H}, \mathbf{L}^{\prime}-\mathrm{H}_{\mathrm{CH} 3}\right), 2.34\left(\mathrm{t}, J=7.4 \mathrm{~Hz}, 2 \mathrm{H}, \mathbf{L} 3-H_{\mathrm{CH} 2}\right), 2.29\left(\mathrm{~s}, 2 \mathrm{H}, \mathrm{L} 3-\mathrm{H}_{\mathrm{CH} 2}\right), 2.22\left(\mathrm{~s}, 3 \mathrm{H}, \mathrm{L} 3-\mathrm{H}_{\mathrm{CH} 3}\right), 2.01(\mathrm{~d}$, $\left.J=6.2 \mathrm{~Hz}, 6 \mathrm{H}, 2 \times \mathbf{L} 3-H_{\mathrm{CH} 3}-\mathrm{Ph}\right), 1.88\left(\mathrm{~s}, 2 \mathrm{H}, 2 \times \mathbf{L} 3-H_{\mathrm{CH} 2}\right), 1.88-1.76\left(\mathrm{~m}, 8 \mathrm{H}, 2 \times \mathbf{L}_{3}-H_{\mathrm{CH} 2}\right), 1.72-1.59(\mathrm{~m}$, $\left.8 \mathrm{H}, 4 \times \mathrm{L} 3-H_{\mathrm{CH} 2}\right), 1.53\left(\mathrm{~s}, 8 \mathrm{H}, 2 \times \mathrm{L}_{3}-\mathrm{H}_{\mathrm{CH} 2}\right) .{ }^{13} \mathrm{C}-\mathrm{NMR}\left(\mathrm{CDCl}_{3}, 100 \mathrm{MHz}, \mathrm{TMS}\right): \delta 173.7,167.5,156.6$, 155.0, 148.1,147.5, 146.4, 138.2, 137.5, 135.9, 134.4, 134.0, 127.9, 127.8,127.7, 125.3, 125.1, 124.9, 124.6, 123.7, 123.4, 121.7, 118.5, 38.4, 35.5, 34.4, 33.9, 33.3, 32.7, 31.9, 27.2, 26.9, 26.8, 26.6, 26.5, 26.2, 24.0, 18.8, 18.7, 18.4, 17.4. FT-IR $\left(\mathrm{KBr}, \mathrm{cm}^{-1}\right): 3377\left(v_{\mathrm{N}-\mathrm{H}}, \mathrm{w}\right), 2952(\mathrm{~s}), 2865(\mathrm{~m}), 1644\left(v_{\mathrm{C}=\mathrm{N}}, \mathrm{m}\right), 1567(\mathrm{w}), 1456(\mathrm{~s}), 1363(\mathrm{~m})$, $1304(\mathrm{w}), 1267(\mathrm{~m}), 1198(\mathrm{~m}), 1164(\mathrm{w}), 1123(\mathrm{w}), 1090(\mathrm{~m}), 1033(\mathrm{w}), 851$ (w), $806(\mathrm{w}), 749(\mathrm{~s})$. Anal. Calcd for $\mathrm{C}_{42} \mathrm{H}_{55} \mathrm{~N}_{3}: \mathrm{C}, 83.81, \mathrm{H}, 9.21, \mathrm{~N}, 6.98$; Found: C, 84.12, H, 9.06, N, 6.68\%.

$\mathrm{Ar}=2-\left(\mathrm{C}_{5} \mathrm{H}_{9}\right)-6-\mathrm{Me}_{2} \mathrm{C}_{6} \mathrm{H}_{2}\left(\mathbf{L} \mathbf{L} / \mathbf{L} \mathbf{4}^{\prime}\right)$. Using a similar procedure and molar ratios to that described for L1/ $\mathbf{L 1}^{\prime}$ but with 2-cyclopentyl-4,6-dimethylphenylamine hydrochloride as the amine, $\mathbf{L 4} / \mathbf{L 4}^{\prime}$ was obtained as a yellow powder $\left(0.20 \mathrm{~g}, 36.6 \%\right.$ ) with molar ratio of $\mathbf{L 4} / \mathbf{L} \mathbf{4}^{\prime}=1 / 0.09$ (detected by ${ }^{1} \mathrm{H}-\mathrm{NMR}$ ). ${ }^{1} \mathrm{H}-\mathrm{NMR}\left(\mathrm{CDCl}_{3}, 400 \mathrm{MHz}, \mathrm{TMS}\right): \delta 8.39\left(\mathrm{t}, J=6.9 \mathrm{~Hz}, 1 \mathrm{H}, \mathbf{L} 4-H_{\mathrm{Py}}\right), 8.26\left(\mathrm{~d}, J=8.2 \mathrm{~Hz}, 1 \mathrm{H}, \mathbf{L} 4^{\prime}-H_{\mathrm{Py}}\right)$, $7.69\left(\mathrm{~d}, J=7.6 \mathrm{~Hz}, 1 \mathrm{H}, \mathbf{L} 4^{\prime}-H_{\mathrm{Py}}\right), 7.61\left(\mathrm{~d}, J=8.3 \mathrm{~Hz}, 1 \mathrm{H}, \mathbf{L} 4-H_{\mathrm{Py}}\right), 7.18\left(\mathrm{t}, J=8.5 \mathrm{~Hz}, 2 \mathrm{H}, 2 \times \mathbf{L} 4-H_{\mathrm{Ar}}\right)$, $7.13\left(\mathrm{t}, J=5.6 \mathrm{~Hz}, 2 \mathrm{H}, 2 \times \mathbf{L} 4^{\prime}-H_{\mathrm{Ar}}\right), 7.07\left(\mathrm{t}, J=6.8 \mathrm{~Hz}, 2 \mathrm{H}, 2 \times \mathbf{L} \mathbf{4}-H_{\mathrm{Ar}}\right.$ and $\left.2 \times \mathbf{L} 4^{\prime}-H_{\mathrm{Ar}}\right), 6.97(\mathrm{~d}$, $\left.\mathrm{J}=7.2 \mathrm{~Hz}, 2 \mathrm{H}, 2 \times \mathbf{L} 4-H_{\mathrm{Ar}}\right), 6.82\left(\mathrm{~d}, J=6.7 \mathrm{~Hz}, 2 \mathrm{H}, 2 \times \mathbf{L 4}^{\prime}-H_{\mathrm{Ar}}\right), 6.46\left(\mathrm{~s}, 1 \mathrm{H}, \mathbf{L} 4^{\prime}-H_{\mathrm{NH}}\right), 4.66(\mathrm{t}$, $\left.J=7.2 \mathrm{~Hz}, 1 \mathrm{H}, \mathbf{L} 4^{\prime}-H_{\mathrm{CH}=}\right), 3.01-2.94\left(\mathrm{~m}, 2 \mathrm{H}, \mathbf{L} 4-H_{\mathrm{CH} 2}\right), 2.89-2.78\left(\mathrm{~m}, 2 \mathrm{H}, \mathbf{L} 4-H_{\mathrm{CH} 2}\right), 2.77(\mathrm{t}, J=6.3 \mathrm{~Hz}$, $\left.2 \mathrm{H}, \mathbf{L}^{\prime}{ }^{\prime}-H_{\mathrm{CH} 2}\right), 2.37\left(\mathrm{~s}, 3 \mathrm{H}, \mathbf{L}^{\prime}-\mathrm{H}_{\mathrm{CH} 2}\right), 2.34\left(\mathrm{t}, J=6.1 \mathrm{~Hz}, 2 \mathrm{H}, \mathbf{L} 4-\mathrm{H}_{\mathrm{CH} 2}\right), 2.26\left(\mathrm{~s}, 2 \mathrm{H}, \mathbf{L} 4-\mathrm{H}_{\mathrm{CH} 2}\right), 2.21(\mathrm{~s}$, $\left.3 \mathrm{H}, \mathbf{L} 4-H_{\mathrm{CH} 3}\right), 2.01\left(\mathrm{~d}, J=6.2 \mathrm{~Hz}, 6 \mathrm{H}, 2 \times \mathbf{L} 4-H_{\mathrm{CH} 3-\mathrm{Ph}}\right), 1.96\left(\mathrm{~s}, 6 \mathrm{H}, 2 \times \mathbf{L} 4-H_{\mathrm{CH} 3-\mathrm{Ph}}\right), 1.88-1.83(\mathrm{~m}$, $\left.2 \mathrm{H}, 2 \times \mathbf{L} 4-H_{\mathrm{CH} 2}\right), 1.81\left(\mathrm{~s}, 4 \mathrm{H}, \mathbf{L} 4-H_{\mathrm{CH} 2}\right), 1.74\left(\mathrm{t}, J=5.7 \mathrm{~Hz}, 4 \mathrm{H}, \mathbf{L} 4-H_{\mathrm{CH} 2}\right), 1.61(\mathrm{~d}, J=5.3 \mathrm{~Hz}, 4 \mathrm{H}$, L4- $\left.H_{\mathrm{CH} 2}\right), 1.54\left(\mathrm{~s}, 4 \mathrm{H}, \mathbf{L} 4-H_{\mathrm{CH} 2}\right) .{ }^{13} \mathrm{C}-\mathrm{NMR}\left(\mathrm{CDCl}_{3}, 100 \mathrm{MHz}, \mathrm{TMS}\right): \delta 173.4,167.3,156.6,155.1,147.9$, 137.6, 136.2, 134.5, 134.2, 128.1, 127.9, 125.3, 125.3 125.3, 123.8, 124.1, 123.9, 123.7, 123.3, 121.8, 40.6, 40.2, $34.3,34.1,33.8,33.7,32.4,31.6,27.3,26.3,26.0,25.9,25.8,24.0,23.1,18.5,17.4,16.9$. FT-IR $\left(\mathrm{KBr}_{\mathrm{cm}}{ }^{-1}\right)$ : $3376\left(v_{\mathrm{N}-\mathrm{H}}, \mathrm{w}\right), 2949(\mathrm{~s}), 2869(\mathrm{~m}), 1646\left(v_{\mathrm{C}=\mathrm{N}}, \mathrm{m}\right), 1565(\mathrm{w}), 1458(\mathrm{~s}), 1363(\mathrm{~m}), 1307(\mathrm{w}), 1264(\mathrm{~m}), 1195$ $(\mathrm{m}), 1164(\mathrm{w}), 1119(\mathrm{w}), 1091(\mathrm{~m}), 1033(\mathrm{w}), 849(\mathrm{w}), 804(\mathrm{w}), 747(\mathrm{~s})$. Anal. Calcd for $\mathrm{C}_{38} \mathrm{H}_{47} \mathrm{~N}_{3}$ : C, 83.62, H, 8.68, N, 7.70; Found: C, 83.37, H, 8.92, N, 7.59\%.

$\mathrm{Ar}=2-\left(\mathrm{C}_{6} \mathrm{H}_{11}\right)-6-\mathrm{Me}_{2} \mathrm{C}_{6} \mathrm{H}_{2}\left(\mathbf{L}\right.$ / $\left./ \mathbf{L}^{\prime}\right)$. Using a similar procedure and molar ratios to that described for $\mathbf{L 1} / \mathbf{L} \mathbf{1}^{\prime}$ but with 2-cyclohexyl-4,6-dimethylphenylamine hydrochloride as the amine, $\mathbf{L 5} / \mathbf{L} \mathbf{5}^{\prime}$ was 
obtained as a yellow powder $\left(0.22 \mathrm{~g}, 38.5 \%\right.$ ) with molar ratio of $\mathbf{L} \mathbf{5} / \mathbf{L} \mathbf{5}^{\prime}=1 / 0.12$ (detected by ${ }^{1} \mathrm{H}-\mathrm{NMR}$ ). ${ }^{1} \mathrm{H}-\mathrm{NMR}\left(\mathrm{CDCl}_{3}, 400 \mathrm{MHz}, \mathrm{TMS}\right): \delta 8.37$ (t, $\left.J=8.4 \mathrm{~Hz}, 1 \mathrm{H}, \mathrm{L} 5-H_{\mathrm{Py}}\right), 8.24\left(\mathrm{~d}, J=8.0 \mathrm{~Hz}, 1 \mathrm{H}, \mathbf{L 5}^{\prime}-H_{\mathrm{Py}}\right)$, $7.66\left(\mathrm{~d}, J=7.6 \mathrm{~Hz}, 1 \mathrm{H}, \mathbf{L 5}^{\prime}-H_{\mathrm{Py}}\right), 7.62\left(\mathrm{~d}, J=7.6 \mathrm{~Hz}, 1 \mathrm{H}, \mathbf{L} 5-H_{\mathrm{Py}}\right), 7.14\left(\mathrm{t}, J=8.1 \mathrm{~Hz}, 2 \mathrm{H}, 2 \times \mathbf{L}-H_{\mathrm{Ar}}\right.$ and $\left.2 \times \mathbf{L 5}^{\prime}-H_{\mathrm{Ar}}\right), 7.02\left(\mathrm{~m}, 2 \mathrm{H}, 2 \times \mathbf{L} 5-H_{\mathrm{Ar}}\right.$ and $\left.2 \times \mathbf{L 5}^{\prime}-H_{\mathrm{Ar}}\right), 6.96\left(\mathrm{~d}, J=7.1 \mathrm{~Hz}, 2 \mathrm{H}, 2 \times \mathbf{L} 5-H_{\mathrm{Ar}}\right)$, $6.93\left(\mathrm{~s}, 2 \mathrm{H}, 2 \times \mathbf{L 5}^{\prime}-H_{\mathrm{Ar}}\right), 6.40\left(\mathrm{~s}, 1 \mathrm{H}, \mathbf{L}^{\prime}-H_{\mathrm{NH}}\right), 4.65\left(\mathrm{t}, J=6.9 \mathrm{~Hz}, 1 \mathrm{H}, \mathbf{L}^{\prime}-H_{\mathrm{CH}=}\right), 2.94(\mathrm{t}, J=6.7 \mathrm{~Hz}$, 2H, L5- $\left.H_{\mathrm{CH} 2}\right), 2.83-2.76\left(\mathrm{~m}, 2 \mathrm{H}, \mathbf{L} 5-H_{\mathrm{CH} 2}\right), 2.67\left(\mathrm{~s}, 2 \mathrm{H}, \mathbf{L 5}^{\prime}-H_{\mathrm{CH} 2}\right), 2.42\left(\mathrm{~s}, 3 \mathrm{H}, \mathbf{L 5}^{\prime}-\mathrm{H}_{\mathrm{CH} 3}\right), 2.38(\mathrm{t}$, $\left.J=6.4 \mathrm{~Hz}, 2 \mathrm{H}, \mathbf{L} 5-H_{\mathrm{CH} 2}\right), 2.31\left(\mathrm{~s}, 2 \mathrm{H}, \mathbf{L} 5-H_{\mathrm{CH} 2}\right), 2.26\left(\mathrm{~s}, 3 \mathrm{H}, \mathbf{L} 5-H_{\mathrm{CH} 2}\right), 2.05(\mathrm{~d}, J=5.0 \mathrm{~Hz}, 6 \mathrm{H}, 2 \times$ L5- $\left.H_{\mathrm{CH} 3-\mathrm{Ph}}\right), 2.01$ (s, 6H, $2 \times$ L5- $\left.H_{\mathrm{CH} 3-\mathrm{Ph}}\right), 1.97$ (s, 2H, $2 \times$ L5$\left.-H_{\mathrm{CH} 2}\right), 1.88-1.82\left(\mathrm{~m}, 4 \mathrm{H}, \mathbf{L} 5-H_{\mathrm{CH} 2}\right)$, $1.77-1.65\left(\mathrm{~m}, 8 \mathrm{H}, 2 \times \mathbf{L} 5-H_{\mathrm{CH} 2}\right), 1.54\left(\mathrm{~s}, 8 \mathrm{H}, 2 \times \mathbf{L} 5-H_{\mathrm{CH} 2}\right) .{ }^{13} \mathrm{C}-\mathrm{NMR}\left(\mathrm{CDCl}_{3}, 100 \mathrm{MHz}, \mathrm{TMS}\right): \delta 174.1$, $167.8,156.9,155.4,148.2,137.7,146.4,138.3,137.5,135.9,135.7,135.4,128.2,128.0,124.4,124.1,123.5$, 123.3, 39.4, 39.0, 34.3, 33.7, 33.4, 33.1, 32.4, 31.2, 27.6, 27.4, 26.5, 26.3, 24.0, 18.6, 17.2. FT-IR $\left(\mathrm{KBr}, \mathrm{cm}^{-1}\right)$ : $3379\left(v_{\mathrm{N}-\mathrm{H}}, \mathrm{w}\right), 2951(\mathrm{~s}), 2864(\mathrm{~m}), 1645\left(v_{\mathrm{C}=\mathrm{N}}, \mathrm{m}\right), 1563(\mathrm{w}), 1457(\mathrm{~s}), 1364(\mathrm{~m}), 1301(\mathrm{w}), 1272(\mathrm{~m}), 1194$ $(\mathrm{m}), 1164(\mathrm{w}), 1120(\mathrm{w}), 1089(\mathrm{~m}), 1034(\mathrm{w}), 850(\mathrm{w}), 804(\mathrm{w}), 748(\mathrm{~s})$. Anal. Calcd for $\mathrm{C}_{40} \mathrm{H}_{51} \mathrm{~N}_{3}$ : C, 83.72, H, 8.96, N, 7.32; Found: C, 83.45, H, 8.73, N, 7.58\%.

$\mathrm{Ar}=2-\left(\mathrm{C}_{8} \mathrm{H}_{15}\right)-6-\mathrm{Me}_{2} \mathrm{C}_{6} \mathrm{H}_{2}\left(\mathbf{L 6} / \mathbf{L} \mathbf{6}^{\prime}\right)$. Using a similar procedure and molar ratios to that described for $\mathbf{L 1} / \mathbf{L 1}^{\prime}$ but with 2-cyclooctyl-4,6-dimethylphenylamine hydrochloride as the amine, $\mathbf{L 6}$ / $\mathbf{L} \mathbf{6}^{\prime}$ was obtained as a yellow powder $(0.20 \mathrm{~g}, 32.1 \%)$ with crude molar ratio of $\mathbf{L 6} / \mathbf{L} \mathbf{6}^{\prime}=1 / 0.21$ (detected by $\left.{ }^{1} \mathrm{H}-\mathrm{NMR}\right) .{ }^{1} \mathrm{H}-\mathrm{NMR}\left(\mathrm{CDCl}_{3}, 400 \mathrm{MHz}, \mathrm{TMS}\right): \delta 8.41$ (m, 1H, L6- $\left.\mathrm{H}_{\mathrm{Py}}\right), 8.27$ (d, J = 7.6 Hz, $\left.1 \mathrm{H}, \mathbf{L 6} \mathbf{c}^{\prime}-\mathrm{H}_{\mathrm{Py}}\right)$, $7.70\left(\mathrm{~d}, J=7.3 \mathrm{~Hz}, 1 \mathrm{H}, \mathbf{L} \mathbf{6}^{\prime}-H_{\mathrm{Py}}\right), 7.66\left(\mathrm{~d}, J=8.0 \mathrm{~Hz}, 1 \mathrm{H}, \mathbf{L} \mathbf{6}-H_{\mathrm{Py}}\right), 7.15\left(\mathrm{t}, J=6.1 \mathrm{~Hz}, 2 \mathrm{H}, 2 \times \mathbf{L} 6-H_{\mathrm{Ar}}\right.$ and $\left.2 \times \mathbf{L} 6^{\prime}-H_{\mathrm{Ar}}\right), 7.11-6.99\left(\mathrm{~m}, 2 \mathrm{H}, 2 \times \mathbf{L} \mathbf{6}-H_{\mathrm{Ar}}\right.$ and $\left.2 \times \mathbf{L 6}^{\prime}-H_{\mathrm{Ar}}\right), 6.94\left(\mathrm{~d}, \mathrm{~J}=7.7 \mathrm{~Hz}, 2 \mathrm{H}, 2 \times \mathbf{L} \mathbf{6}-H_{\mathrm{Ar}}\right.$ and $\left.2 \times \mathbf{L 6}^{\prime}-H_{\mathrm{Ar}}\right), 6.38\left(\mathrm{~s}, 1 \mathrm{H}, \mathbf{L} \mathbf{6}^{\prime}-H_{\mathrm{NH}}\right), 4.66\left(\mathrm{t}, J=6.9 \mathrm{~Hz}, 1 \mathrm{H}, \mathbf{L} \mathbf{6}^{\prime}-H_{\mathrm{CH}=}\right), 3.07-3.01\left(\mathrm{~m}, 2 \mathrm{H}, \mathbf{L} \mathbf{6}-H_{\mathrm{CH} 2}\right)$, 2.81-2.75 (m, 2H, L6- $\left.H_{\mathrm{CH} 2}\right), 2.42\left(\mathrm{~s}, 3 \mathrm{H}, \mathbf{L 6}^{\prime}-\mathrm{H}_{\mathrm{CH} 3}\right), 2.35\left(\mathrm{t}, J=7.4 \mathrm{~Hz}, 2 \mathrm{H}, \mathbf{L} 6-H_{\mathrm{CH} 2}\right), 2.33(\mathrm{~s}, 2 \mathrm{H}$, L6- $\left.\mathrm{H}_{\mathrm{CH} 2}\right), 2.25\left(\mathrm{~s}, 3 \mathrm{H}, \mathrm{L6}-H_{\mathrm{CH} 3}\right), 2.11\left(\mathrm{~d}, J=6.0 \mathrm{~Hz}, 6 \mathrm{H}, 2 \times\right.$ L6$\left.-H_{\mathrm{CH} 3-\mathrm{Ph}}\right), 2.03(\mathrm{~d}, J=5.9 \mathrm{~Hz}, 6 \mathrm{H}, 2$ $\times$ L6- $\left.H_{\mathrm{CH} 3-\mathrm{Ph}}\right), 1.90\left(\mathrm{~s}, 2 \mathrm{H}, 2 \times \mathbf{L}-H_{\mathrm{CH} 2}\right), 1.88-1.76\left(\mathrm{~m}, 8 \mathrm{H}, 2 \times \mathbf{L}-H_{\mathrm{CH} 2}\right), 1.71-1.60(\mathrm{~m}, 8 \mathrm{H}, 4 \times$ L6- $\left.H_{\mathrm{CH} 2}\right), 1.51\left(\mathrm{~s}, 8 \mathrm{H}, 2 \times\right.$ L6- $\left._{\mathrm{CH} 2}\right) .{ }^{13} \mathrm{C}-\mathrm{NMR}\left(\mathrm{CDCl}_{3}, 100 \mathrm{MHz}, \mathrm{TMS}\right): \delta 174.6,168.1,157.3,155.5$, $148.5,147.9,146.6,138.3,137.8,136.2,134.4,134.1,128.3,127.9,127.7,125.7,125.4,124.9,124.8,123.7$, 123.6, 121.9, 118.5, 38.4, 36.0, 34.6, 33.9, 33.4, 32.5, 32.0, 27.4, 26.9, 26.7, 26.4, 26.3, 26.0, 24.1, 18.8, 18.6, 18.2, 17.4. FT-IR (KBr, cm $\left.{ }^{-1}\right)$ : $3374\left(v_{\mathrm{N}-\mathrm{H}}, \mathrm{w}\right), 2948(\mathrm{~s}), 2865(\mathrm{~m}), 1644\left(v_{\mathrm{C}=\mathrm{N}}, \mathrm{m}\right), 1565(\mathrm{w}), 1459(\mathrm{~s}), 1361$ (m), 1303 (w), $1263(\mathrm{~m}), 1194(\mathrm{~m}), 1165(\mathrm{w}), 1119(\mathrm{w}), 1090(\mathrm{~m}), 1036(\mathrm{w}), 851(\mathrm{w}), 805(\mathrm{w}), 749$ (s). Anal. Calcd for $\mathrm{C}_{44} \mathrm{H}_{59} \mathrm{~N}_{3}$ : C, 83.89, H, 9.44, N, 6.67; Found: C, 83.63, H, 9.26, N, 6.98\%.

\subsection{Synthesis of [2-(1-ArN) $\left.\mathrm{C}_{2} \mathrm{H}_{3}-9-\mathrm{ArN}-5,6,7,8-\mathrm{C}_{5} \mathrm{H}_{8} \mathrm{C}_{5} \mathrm{H}_{3} \mathrm{~N}\right] \mathrm{CoCl}_{2}$ (Co1-Co6)}

$\mathrm{Ar}=2-\left(\mathrm{C}_{5} \mathrm{H}_{9}\right)-6-\mathrm{MeC}_{6} \mathrm{H}_{3}$ (Co1). The ligand $\mathbf{L 1} / \mathbf{L 1}{ }^{\prime}(110.0 \mathrm{mg}, 0.23 \mathrm{mmol})$ and $\mathrm{CoCl}_{2} \cdot 6 \mathrm{H}_{2} \mathrm{O}(47.3 \mathrm{mg}$, $0.20 \mathrm{mmol}$ ) were dissolved in $5 \mathrm{~mL}$ of ethanol. The reaction mixture was stirred at room temperature for overnight after which time diethyl ether $(30 \mathrm{~mL})$ was added to precipitate the complex. The precipitate was collected by filtration and washed with diethyl ether $(3 \times 5 \mathrm{~mL})$, followed by drying under vacuum to give complex Co1 as a light brown powder (122.0 mg, 94.0\%). FT-IR ( $\left.\mathrm{KBr}, \mathrm{cm}^{-1}\right)$ : $2947(\mathrm{~s})$, $2863(\mathrm{~m}), 2167(\mathrm{w}), 2138(\mathrm{w}), 2012(\mathrm{w}), 1992(\mathrm{w}), 1608\left(v_{\mathrm{C}=\mathrm{N}}, \mathrm{m}\right), 1571(\mathrm{~s}), 1454(\mathrm{~s}), 1369(\mathrm{~m}), 1309(\mathrm{w})$, 1257 (s), 1198 (s), $1113(\mathrm{~m}), 1086(\mathrm{w}), 934(\mathrm{w}), 888(\mathrm{w}), 845$ (m), 744 (vs). Anal. Calcd for $\mathrm{C}_{36} \mathrm{H}_{43} \mathrm{Cl}_{2} \mathrm{CoN}_{3}$ : C, 66.77, H, 6.69, N, 6.49; Found: C, 66.42, H, 6.61, N, 6.55\%.

$\mathrm{Ar}=2-\left(\mathrm{C}_{6} \mathrm{H}_{11}\right)-6-\mathrm{MeC}_{6} \mathrm{H}_{3}(\mathbf{C o} 2)$. Using a similar procedure and molar ratios to that described for $\mathbf{C o 1}$ but with L2/L2' as the ligand, the complex Co2 was obtained as the light brown powder in $126.0 \mathrm{mg}$ (yield: 93.5\%). FT-IR (KBr, cm $\left.{ }^{-1}\right)$ : $2923(\mathrm{~s}), 2851(\mathrm{~m}), 2168(\mathrm{w}), 2119(\mathrm{w}), 2022(\mathrm{w}), 1989(\mathrm{w}), 1606\left(v_{\mathrm{C}=\mathrm{N}}\right.$, m), 1570 (s), 1448 (s), 1369 (m), $1314(\mathrm{w}), 1260$ (m), 1230 (s), 1194 (s), $1114(\mathrm{~m}), 1088(\mathrm{w}), 936(\mathrm{w}), 886$ (w), $846(\mathrm{~m}), 774(\mathrm{vs}), 736(\mathrm{w})$. Anal. Calcd for $\mathrm{C}_{38} \mathrm{H}_{47} \mathrm{Cl}_{2} \mathrm{CoN}_{3}$ : C, 67.55, H, 7.01, N, 6.22; Found: C, $67.77, \mathrm{H}, 6.94, \mathrm{~N}, 6.34 \%$.

$\mathrm{Ar}=2-\left(\mathrm{C}_{8} \mathrm{H}_{15}\right)-6-\mathrm{MeC}_{6} \mathrm{H}_{3}(\mathrm{Co} 3)$. Using a similar procedure and molar ratios to that described for Co1 but with $\mathbf{L 3} / \mathbf{L 3}^{\prime}$ as the ligand, the complex Co3 was obtained as the light brown powder in $130.0 \mathrm{mg}$ 
(yield: 91.2\%). FT-IR (KBr, cm $\left.{ }^{-1}\right)$ : $2916(\mathrm{~s}), 2853(\mathrm{~m}), 2167(\mathrm{w}), 2082(\mathrm{w}), 2014(\mathrm{w}), 1989(\mathrm{w}), 1609\left(v_{\mathrm{C}=\mathrm{N}}\right.$, m), 1569 (s), 1465 (s), 1368 (m), 1313 (w), 1257 (s), 1193 (s), 1114 (m), 1085 (w), 931 (w), 845 (m), 771 (vs), 735 (w). Anal. Calcd for $\mathrm{C}_{42} \mathrm{H}_{55} \mathrm{Cl}_{2} \mathrm{CoN}_{3}$ : C, 68.94, H, 7.58, N, 5.74; Found: C, 69.31, H, 7.47, N, 5.89\%.

$\mathrm{Ar}=2-\left(\mathrm{C}_{5} \mathrm{H}_{9}\right)-4,6-\mathrm{Me}_{2} \mathrm{C}_{6} \mathrm{H}_{2}(\mathrm{Co} 4)$. Using a similar procedure and molar ratios to that described for Co1 but with $\mathbf{L} 4 / \mathbf{L 4}^{\prime}$ as the ligand, the complex Co4 was obtained as the light brown powder in $126.0 \mathrm{mg}$ (yield: 93.3\%). FT-IR (KBr, cm $\left.{ }^{-1}\right)$ : $2916(\mathrm{~s}), 2857(\mathrm{~m}), 2166(\mathrm{w}), 2078(\mathrm{w}), 2032(\mathrm{w}), 1991(\mathrm{w}), 1609$ ( v $\left._{\mathrm{C}=\mathrm{N}}, \mathrm{m}\right)$, 1569 (s), 1472 (s), 1448 (s), 1368 (m), 1311 (w), 1257 (s), 1205 (s), 1113 (m), 1085 (w), 926 (w), 850 (s), 768 (s). Anal. Calcd for $\mathrm{C}_{38} \mathrm{H}_{47} \mathrm{Cl}_{2} \mathrm{CoN}_{3}$ : C, 67.55, H, 7.01, N, 6.22; Found: C, 67.82, H, 7.31, N, 6.06\%.

Ar $=2-\left(\mathrm{C}_{6} \mathrm{H}_{11}\right)-4,6-\mathrm{Me}_{2} \mathrm{C}_{6} \mathrm{H}_{2}$ (Co5). Using a similar procedure and molar ratios to that described for Co1 but with $\mathbf{L 5} / \mathbf{L 5}^{\prime}$ as the ligand, the complex Co5 was obtained as the light brown powder in 135.0 mg (yield: 95.6\%). FT-IR (KBr, cm ${ }^{-1}$ ): 2918 (vs), 2852 (s), 2169 (w), 2111 (w), 2011 (w), 1989 (w), $1611\left(v_{\mathrm{C}=\mathrm{N}}, \mathrm{m}\right), 1569(\mathrm{~s}), 1447(\mathrm{~s}), 1367(\mathrm{~m}), 1313(\mathrm{w}), 1258(\mathrm{~s}), 1204(\mathrm{~m}), 1116(\mathrm{w}), 1086(\mathrm{w}), 850(\mathrm{~s}), 768$ (s). Anal. Calcd for $\mathrm{C}_{40} \mathrm{H}_{51} \mathrm{Cl}_{2} \mathrm{CoN}_{3}$ : C, 68.27, H, 7.31, N, 5.97; Found: C, 67.89, H, 7.47, N, 6.33\%.

$\mathrm{Ar}=2-\left(\mathrm{C}_{8} \mathrm{H}_{15}\right)-4,6-\mathrm{Me}_{2} \mathrm{C}_{6} \mathrm{H}_{2}$ (Co6). Using a similar procedure and molar ratios to that described for Co1 but with $\mathbf{L 6}$ / $\mathbf{L 6}^{\prime}$ as the ligand, the complex Co6 was obtained as the light brown powder in 133.0 mg (yield: 87.4\%). FT-IR (KBr, cm $\left.{ }^{-1}\right)$ : 2916 (s), $2854(\mathrm{~m}), 2166$ (w), $2112(\mathrm{w}), 2012(\mathrm{w}), 1990$ (w), $1611\left(v_{\mathrm{C}=\mathrm{N}}, \mathrm{m}\right), 1568(\mathrm{~s}), 1466(\mathrm{~s}), 1441(\mathrm{~s}), 1368(\mathrm{~m}), 1314(\mathrm{w}), 1257(\mathrm{~m}), 1212(\mathrm{~m}), 1114(\mathrm{w}), 1084(\mathrm{w})$, 926 (w), 852 (s), 768 (s). Anal. Calcd for $\mathrm{C}_{44} \mathrm{H}_{59} \mathrm{Cl}_{2} \mathrm{CoN}_{3}$ : C, 69.55, H, 7.83, N, 5.53; Found: C, 69.81, H, $7.58, \mathrm{~N}, 5.85 \%$.

\subsection{X-ray Crystallographic Studies}

Single-crystal X-ray diffraction studies of Co1 and Co3 were conducted on a Rigaku Sealed Tube CCD (Saturn 724+) diffractometer with graphite-mono chromated Mo-K $\alpha$ radiation $(\lambda=0.71073 \AA)$ at $173(2) \mathrm{K}$ and the cell parameters obtained by global refinement of the positions of all collected reflections. Intensities were corrected for Lorentz and polarization effects and empirical absorption. The structures were solved by direct methods and refined by full-matrix least-squares on $\mathrm{F}^{2}$. All non-hydrogen atoms were refined anisotropically and all hydrogen atoms were placed in calculated positions. Structure solution and refinement were performed by using the SHELXT (Sheldrick, 2015) [55]. The disorder displayed by the carbon atoms in Co3 was processed by the SHELXL-2015 software [56]. Crystal data and processing parameters for $\mathbf{C o} 2$ and Co3 are summarized in Table 4. X-ray crystallographic data in CIF for the Cambridge Crystallographic Data Centre (CCDC) 1,897,124 (Co2) and 1,897,125 (Co3) are available free of charge from The Cambridge Crystallographic Data Centre.

Table 4. Crystal data and structure refinement for Co2 and Co3.

\begin{tabular}{|c|c|c|}
\hline & $\mathrm{Co} 2$ & $\mathrm{Co3}$ \\
\hline Crystal color & Brown & Yellow \\
\hline Formula weight & 675.61 & 731.72 \\
\hline Temperature (K) & 173.15 & $173.15(2)$ \\
\hline Wavelength $(\AA)$ & 0.71073 & 0.71073 \\
\hline a $(\AA)$ & $33.4157(6)$ & $34.3337(8)$ \\
\hline b $(\AA)$ & $31.4531(6)$ & $34.3337(8)$ \\
\hline c $(\AA)$ & $16.9829(4)$ & $14.5297(7)$ \\
\hline$\alpha\left(^{\circ}\right)$ & 90 & 90 \\
\hline$\beta\left(^{\circ}\right)$ & 90 & 90 \\
\hline$\gamma\left({ }^{\circ}\right)$ & 90 & 90 \\
\hline$\mu\left(\mathrm{mm}^{-1}\right)$ & 0.528 & 0.555 \\
\hline$F(000)$ & 5712.0 & 6224.0 \\
\hline
\end{tabular}


Table 4. Cont

\begin{tabular}{ccc}
\hline & Co2 & Co3 \\
\hline Crystal size $\left(\mathrm{mm}^{3}\right)$ & $0.288 \times 0.193 \times 0.102$ & $0.274 \times 0.144 \times 0.118$ \\
$\theta$ rang $\left({ }^{\circ}\right)$ & $4.56-63.054$ & $3.044-66.158$ \\
Limiting indices & $-46 \leq h \leq 48,-43 \leq k \leq 46,-24 \leq l \leq 23$ & $-50 \leq \mathrm{h} \leq 48,-47 \leq \mathrm{k} \leq 51,-21 \leq 1 \leq 10$ \\
No. of rflns collected & 70088 & 49080 \\
No. unique rflns [R(int)] & $0.0625(10266)$ & $0.1028(4627)$ \\
Completeness to $\theta(\%)$ & $93.0(\theta=25.00)$ & $90.6(\theta=25.00)$ \\
Goodness of fit on $F^{2}$ & 1.040 & 0.971 \\
Final $\mathrm{R}$ indices $[\mathrm{I}>2 \sigma(\mathrm{I})]$ & $\mathrm{R}_{1}=0.0625, \mathrm{wR} \mathrm{R}_{2}=0.1560$ & $\mathrm{R}_{1}=0.1028, \mathrm{wR} \mathrm{R}_{2}=0.2154$ \\
$\mathrm{R}$ indices (all data) & $\mathrm{R}_{1}=0.0868, \mathrm{wR} \mathrm{R}_{2}=0.1705$ & $\mathrm{R}_{1}=0.2894, \mathrm{wR} \mathrm{R}_{2}=0.3034$ \\
Largest diff. peak and hole $\left(\mathrm{e} \AA^{-3}\right)$ & 0.41 and -0.21 & 0.42 and -0.42 \\
\hline
\end{tabular}

\subsection{General Procedure for Ethylene Polymerization under 5/10 Atm Pressure}

A $250 \mathrm{~mL}$ stainless steel autoclave (Dalian Sanling Electronic Manufacture, Dalian, China), equipped with an ethylene pressure control system, a mechanical stirrer and a temperature controller, was employed for the reaction. The autoclave was evacuated and refilled with ethylene three times. When the desired reaction temperature was reached, toluene, the co-catalyst (MAO or MMAO), and a toluene solution of the catalytic precursor (the total volume was $100 \mathrm{~mL}$ ) were injected into the autoclave by using syringes. Then, the ethylene pressure was increased to $5 / 10 \mathrm{~atm}$, maintained at this level with constant feeding of ethylene. After the reaction was carried out for their quired period, the reactor was cooled with a water bath and the excess ethylene was vented. The reaction solution was quenched with $10 \% \mathrm{HCl}$ /ethanol. The precipitated polymer was collected through filtration, washed with ethanol and dried under vacuum at $60^{\circ} \mathrm{C}$ until constant weight.

\section{Conclusions}

A family of six cobalt (II) chloride complexes, Co1-Co6, bound by single ring-fused 2-(1-cycloalkylphenylimino)ethyl-9-cycloalkylphenylimino-5,6,7,8-tetrahydrocyclo-heptapyridines, was prepared by the reaction of the corresponding carbocyclic-fused $N N N$-pincer ligands $\left(\mathbf{L 1} / \mathbf{L 1}^{\prime} \mathbf{-} \mathbf{L} 6 / \mathbf{L 6}^{\prime}\right)$ and cobalt(II) chloride and fully characterized. On activation with either MMAO or MAO, all these ortho cycloalkyl substituted cobalt complexes displayed good activity for ethylene polymerization with the optimum temperature of $50{ }^{\circ} \mathrm{C}$, affording the linear polyethylene. The molecular weight $\left(\mathrm{Mw}=9.78-25.6 \mathrm{~kg} \mathrm{~mol}^{-1}\right)$ is higher than that observed with their analogues D bearing alkyl substituent. The ring size of the ortho substituent greatly affected their molecular weight and polymerization activity, which was demonstrated by the highest activity achieved by the cyclopentyl substituted ones (Co1 and Co4) and the highest molecular weight by cyclooctyl substituted ones (Co3 and Co6). Notably, polyethylene using MAO as activator displayed high selectivity for vinyl end-groups $\left(-\mathrm{CH}=\mathrm{CH}_{2}\right)$, while with $\mathrm{MMAO}$ the polyethylene possessed both the saturated and saturated linear structure.

Author Contributions: Design of the study and experiments, W.Z. and W.-H.S.; synthesis and catalysis, J.G., Z.W., I.I.O., I.V.O. and A.V.; manuscript, W.Z. and W.-H.S.; interpretation of the data obtained from the single crystal X-ray diffraction, Y.S.; chemical support, X.H.

Funding: This work was supported by the National Natural Science Foundation of China (Nos. 51473170, 21871275 and 51861145303) and the Russian Foundation for Basic Research (No. 18-53-80031_BRICS/5171102116). A.V thanks the Chinese Academy of Sciences President's International Fellowship Initiative for the award of post-doctoral fellowship (Grant No. 2018PM0012).

Conflicts of Interest: The authors declare no conflict of interest. 


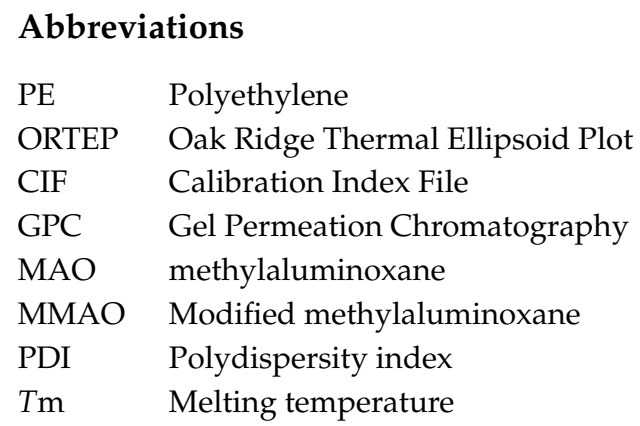

\section{References}

1. Small, B.L.; Brookhart, M.; Bennett, A.M.A. Highly active iron and cobalt catalysts for the polymerization of ethylene. J. Am. Chem. Soc. 1998, 120, 4049-4050. [CrossRef]

2. Small, B.L.; Brookhart, M. Iron-based catalysts with exceptionally high activities and selectivities for oligomerization of ethylene to linear $\alpha$-olefins. J. Am. Chem. Soc. 1998, 120, 7143-7144. [CrossRef]

3. Britovsek, G.J.P.; Gibson, V.C.; Kimberley, B.S.; Maddox, P.J.; McTavish, S.J.; Solan, G.A.; White, A.J.P.; Williams, D.J. Novel olefin polymerization catalysts based on iron and cobalt. Chem. Commun. 1998, 7 , 849-850. [CrossRef]

4. Britovsek, G.J.P.; Bruce, M.; Gibson, V.C.; Kimberley, B.S.; Maddox, P.J.; Mastroianni, S.; McTavish, S.J.; Redshaw, C.; Solan, G.A.; Stromberg, S.; et al. Iron and cobalt ethylene polymerization catalysts bearing 2,6-bis(Imino)pyridyl ligands: Synthesis, structures, and polymerization studies. J. Am. Chem. Soc. 1999, 121, 8728-8740. [CrossRef]

5. Britovsek, G.J.P.; Mastroianni, S.; Solan, G.A.; Baugh, S.P.D.; Redshaw, C.; Gibson, V.C.; White, A.J.P.; Williams, D.J.; Elsegood, M.R. Oligomerisation of ethylene by bis(imino)pyridyliron and -cobalt complexes. Chem. Eur. J. 2000, 6, 2221-2231. [CrossRef]

6. Wang, Z.; Solan, G.A.; Zhang, W.; Sun, W.-H. Carbocyclic-fused $N, N, N$-pincer ligands as ring-strain adjustable supports for iron and cobalt catalysts in ethylene oligo-/polymerization. Coord. Chem. Rev. 2018, 363, 92-108. [CrossRef]

7. Small, B.L. Discovery and development of pyridine-bis(imine) and related catalysts for olefin polymerization and oligomerization. Acc. Chem. Res. 2015, 48, 2599-2611. [CrossRef]

8. Burcher, B.; Breuil, P.-A.R.; Magna, L.; Olivier-Bourbigou, H. Iron-catalyzed oligomerization and polymerization Reactions. Top. Organomet. Chem. 2015, 50, 217-258.

9. Flisak, Z.; Sun, W.-H. Progression of diiminopyridines: From single application to catalytic versatility. ACS Catal. 2015, 5, 4713-4724. [CrossRef]

10. Ma, J.; Feng, C.; Wang, S.; Zhao, K.-Q.; Sun, W.-H.; Redshaw, C.; Solan, G.A. Bi- and tri-dentate imino-based iron and cobalt pre-catalysts for ethylene oligo-/polymerization. Inorg. Chem. Front. 2014, 1, 14-34. [CrossRef]

11. Zhang, W.; Sun, W.-H.; Redshaw, C. Tailoring iron complexes for ethylene oligomerization and/or polymerization. Dalton Trans. 2013, 42, 8988-8997. [CrossRef]

12. Gibson, V.C.; Solan, G.A. Olefin Oligomerizations and Polymerizations Catalyzed by Iron and Cobalt Complexes Bearing Bis(imino)pyridine Ligands. In Catalysis without Precious Metals; Bullock, M., Ed.; Wiley-VCH: Weinheim, Germany, 2010; pp. 111-141.

13. Gibson, V.C.; Solan, G.A. Iron-based and cobalt-based olefin polymerisation catalysts. Top. Organomet. Chem. 2009, 26, 107-158.

14. Gibson, V.C.; Redshaw, C.; Solan, G.A. Bis(imino)pyridines: Surprisingly reactive ligands and a gateway to new families of catalysts. Chem. Rev. 2007, 107, 1745-1776. [CrossRef] [PubMed]

15. Bianchini, C.; Giambastiani, G.; Rios, I.G.; Mantovani, G.; Meli, A.; Segarra, A.M. Ethylene oligomerization, homopolymerization and copolymerization by iron and cobalt catalysts with 2,6-(bis-organylimino)pyridyl ligands. Coord. Chem. Rev. 2006, 250, 1391-1418. [CrossRef]

16. Mahmood, Q.; Guo, J.; Zhang, W.; Ma, Y.; Liang, T.; Sun, W.-H. Concurrently improving the thermal stability and activity of ferrous precatalysts for the production of saturated/unsaturated polyethylene. Organometallics 2018, 37, 957-970. [CrossRef] 
17. Mahmood, Q.; Yue, E.; Guo, J.; Zhang, W.; Ma, Y.; Hao, X.; Sun, W.-H. Nitro-functionalized bis(imino)pyridylferrous chlorides as thermo-stable precatalysts for linear polyethylenes with high molecular weights. Polymer 2018, 159, 124-137. [CrossRef]

18. Semikolenova, N.V.; Sun, W.-H.; Soshnikov, I.E.; Matsko, M.A.; Kolesova, O.V.; Zakharov, V.A.; Bryliakov, K.P. Origin of "multisite-like" ethylene polymerization behavior of the single-site nonsymmetrical bis(imino)pyridine iron(II) complex in the presence of modified methylaluminoxane. ACS Catal. 2017, 7, 2868-2877. [CrossRef]

19. Zhao, W.; Yue, E.; Wang, X.; Yang, W.; Chen, Y.; Hao, X.; Cao, X.; Sun, W.-H. Activity and stability spontaneously enhanced toward ethylene polymerization by employing 2-(1-(2,4-Dibenzhydrylnaphthylimino)ethyl)-6-(1-(arylimino)ethyl)pyridyliron(II) dichlorides. J. Polym. Sci. Part A Polym. Chem. 2017, 55, 988-996. [CrossRef]

20. Mitchell, N.E.; Anderson, W.C.; Long, B.K. Mitigating chain-transfer and enhancing the thermal stability of co-based olefin polymerization catalysts through sterically demanding ligands. J. Polym. Sci. Part A Polym. Chem. 2017, 55, 3990-3996. [CrossRef]

21. Yue, E.; Zeng, Y.; Zhang, W.; Sun, Y.; Cao, X.-P.; Sun, W.-H. Highly linear polyethylenes using the 2-(1-(2,4-dibenzhydrylnaphthylimino)ethyl)-6-(1-(arylimino)ethyl)pyridylcobalt chlorides: Synthesis, characterization and ethylene polymerization. Sci. China Chem. 2016, 59, 1291-1300. [CrossRef]

22. Zhang, W.; Wang, S.; Du, S.; Guo, C.-Y.; Hao, X.; Sun, W.-H. 2-(1-(2,4-Bis((di(4-fluorophenyl)ethyl)methylphenylimino)ethyl)-6-(1-(arylimino)ethyl)pyridylmetal (iron or cobalt) complexes: Synthesis, characterization, and ethylene polymerization behavior. Macromol. Chem. Phys. 2014, 215, 1797-1809. [CrossRef]

23. Wang, S.; Li, B.; Liang, T.; Redshaw, C.; Li, Y.; Sun, W.-H. Synthesis, characterization and catalytic behavior toward ethylene of 2-[1-(4,6-dimethyl-2-benzhydrylphenylimino)ethyl]-6-[1-(arylimino)ethyl] pyridylmetal (iron or cobalt) chlorides. Dalton Trans. 2013, 42, 9188-9197. [CrossRef]

24. Smit, T.M.; Tomov, A.K.; Britovsek, G.J.P.; Gibson, V.C.; White, A.J.P.; Williams, D.J. The effect of imine-carbon substituents in bis(imino)pyridine-based ethylene polymerisation catalysts across the transition series. Catal. Sci. Technol. 2012, 2, 643-655. [CrossRef]

25. Zhao, W.; Yu, J.; Song, S.; Yang, W.; Liu, H.; Hao, X.; Redshaw, C.; Sun, W.-H. Controlling the ethylene polymerization parameters in iron pre-catalysts of thetype 2-[1-(2,4-dibenzhydryl-6-methylphenylimino) ethyl]-6-[1-(arylimino)ethyl] pyridyliron dichloride. Polymer 2012, 53, 130-137. [CrossRef]

26. Cao, X.; He, F.; Zhao, W.; Cai, Z.; Hao, X.; Shiono, T.; Redshaw, C.; Sun, W.-H. 2-[1-(2,6-Dibenzhydryl-4-chlorophenylimino)ethyl]-6-[1-(arylimino)ethyl]pyridyliron(II) dichlorides: Synthesis, characterization and ethylene polymerization behavior. Polymer 2012, 53, 1870-1880. [CrossRef]

27. Lai, J.; Zhao, W.; Yang, W.; Redshaw, C.; Liang, T.; Liu, Y.; Sun, W.-H. 2-[1-(2,4-Dibenzhydryl-6-methylphenylimino)ethyl]-6-[1-(arylimino)ethyl]pyridylcobalt(II) dichlorides: Synthesis, characterization and ethylene polymerization behavior. Polym. Chem. 2012, 3, 787-793. [CrossRef]

28. He, F.; Zhao, W.; Cao, X.-P.; Liang, T.; Redshaw, C.; Sun, W.-H. 2-[1-(2,6-Dibenzhydryl-4-chloro phenylimino)ethyl]-6-[1-aryliminoethyl]pyridylcobalt dichlorides: Synthesis, characterization and ethylene polymerization behavior. J. Organomet. Chem. 2012, 713, 209-216. [CrossRef]

29. Yu, J.; Huang, W.; Wang, L.; Redshaw, C.; Sun, W.-H. 2-[1-(2,6-Dibenzhydryl-4-methylphenylimino) ethyl]-6-[1-(arylimino)ethyl]-pyridylcobalt(II) dichlorides: Synthesis, characterization and ethylene polymerization behavior. Dalton Trans. 2011, 40, 10209-10214. [CrossRef]

30. Yu, J.; Liu, H.; Zhang, W.; Hao, X.; Sun, W.-H. Access to highly active and thermally stable iron procatalysts using bulky 2-[1-(2,6-dibenzhydryl-4-methylphenylimino)ethyl]-6-[1-(arylimino)ethyl] pyridine Ligands. Chem. Commun. 2011, 47, 3257-3259. [CrossRef]

31. Guo, L.; Gao, H.; Zhang, L.; Zhu, F.; Wu, Q. An unsymmetrical iron(II) bis(imino)pyridyl catalyst for ethylene polymerization: Effect of a bulky ortho substituent on the thermostability and molecular weight of polyethylene. Organometallics 2010, 29, 2118-2125. [CrossRef]

32. Wang, L.; Sun, W.-H.; Han, L.; Yang, H.; Hu, Y.; Jin, X. Late transition metal complexes bearing 2,9-bis(imino)-1,10-phenanthrolinyl ligands: Synthesis, characterization and their ethylene activity. J. Organomet. Chem. 2002, 658, 62-70. [CrossRef] 
33. Guo, L.; Zada, M.; Zhang, W.; Vignesh, A.; Zhu, D.; Ma, Y.; Liang, T.; Sun, W.-H. Highly linear polyethylenes tailored by 2,6-bis[1-(p-dibenzo-cycloheptylarylimino)ethyl]pyridylcobalt dichlorides. Dalton Trans. 2019. [CrossRef]

34. Oleinik, I.I.; Oleinik, I.V.; Abdrakhmanov, I.B.; Ivanchev, S.S.; Tolstikov, G.A. Design of arylimine postmetallocene catalytic systems for olefin polymerization: I. Synthesis of substituted 2-cycloalkyl- and 2,6-dicycloalkylanilines. Russ. J. Gen. Chem. 2004, 74, 1423-1427. [CrossRef]

35. Ivancheva, S.S.; Yakimansky, A.V.; Rogozin, G.D. Quantum-chemical calculations of the effect of cycloaliphatic groups in a-diimine and bis(imino)pyridine ethylene polymerization precatalysts on their stabilities with respect to deactivation reactions. Polymer 2004, 45, 6453-6459. [CrossRef]

36. Ivanchev, S.S.; Tolstikov, G.A.; Badaev, V.K.; Oleinik, I.I.; Ivancheva, N.I.; Rogozin, D.G.; Oleinik, I.V.; Myakin, S.V. New bis(arylimino)pyridyl complexes as components of catalysts for ethylene polymerization. Kinet. Catal. 2004, 45, 176-182. [CrossRef]

37. Tolstikov, G.A.; Ivanchev, S.S.; Oleinik, I.I.; Ivancheva, N.I.; Oleinik, I.V. New multifunctional bis(imino)pyridine-iron chloride complexes and ethylene polymerization catalysts on their basis. Dokl. Phys. Chem. 2005, 404, 208-211. [CrossRef]

38. Ba, J.; Du, S.; Yue, E.; Hu, X.; Flisak, Z.; Sun, W.-H. Constrained formation of 2-(1-(arylimino)ethyl)-7-arylimino-6,6-dimethylcyclopentapyridines and their cobalt(II) chloride complexes: Synthesis, characterization and ethylene polymerization. RSC Adv. 2015, 5, 32720-32729. [CrossRef]

39. Sun, W.-H.; Kong, S.; Chai, W.; Shiono, T.; Redshaw, C.; Hu, X.; Guo, C.; Hao, X. 2-(1-(Arylimino)ethyl)-8arylimino-5,6,7-trihydroquinolylcobalt dichloride: Synthesis and polyethylene wax formation. Appl. Catal. A 2012, 447-448, 67-73. [CrossRef]

40. Huang, F.; Zhang, W.; Yue, E.; Liang, T.; Hu, X.; Sun, W.-H. Controlling the molecular weights of polyethylene waxes using the highly active precatalysts of 2-(1-aryliminoethyl)-9-arylimino5,6,7,8-tetrahydrocycloheptapyridylcobalt chlorides: Synthesis, characterization, and catalytic behavior. Dalton Trans. 2016, 45, 657-666. [CrossRef] [PubMed]

41. Huang, F.; Zhang, W.; Sun, Y.; Hu, X.; Solan, G.A.; Sun, W.H. Thermally stable and highly active cobalt precatalysts for vinyl-polyethylenes with narrow polydispersities: Integrating fused-ring and imino-carbon protection into ligand design. New J. Chem. 2016, 40, 8012-8023. [CrossRef]

42. Appukuttan, V.K.; Liu, Y.; Son, B.C.; Ha, C.-S.; Suh, H.; Kim, I. Iron and cobalt complexes of 2,3,7,8-tetrahydroacridine-4,5(1H,6H)-diimine sterically modulated by substituted aryl rings for the selective oligomerization to polymerization of ethylene. Organometallics 2011, 30, 2285-2294. [CrossRef]

43. Du, S.; Zhang, W.; Yue, E.; Huang, F.; Liang, T.; Sun, W.-H. $\alpha, \alpha^{\prime}$-Bis(arylimino)-2,3:5,6-bis(penta methylene)pyridylcobalt chlorides: Synthesis, characterization, and ethylene polymerization behavior. Eur. J. Inorg. Chem. 2016, 1748-1755. [CrossRef]

44. Suo, H.; Oleynik, I.I.; Bariashir, C.; Oleynik, I.V.; Wang, Z.; Solan, G.A.; Ma, Y.; Liang, T.; Sun, W.-H. Strictly linear polyethylene using Co-catalysts chelated by fused bis(arylimino)pyridines: Probing ortho-cycloalkyl ring-size effects on molecular weight. Polymer 2018, 149, 45-54. [CrossRef]

45. Wang, Z.; Ma, Y.; Guo, J.; Liu, Q.; Solan, G.A.; Liang, T.; Sun, W.-H. Bis(imino)pyridines fused with 6- and 7-membered carbocylic rings as $N, N, N$-scaffolds for cobalt ethylene polymerization catalysts. Dalton Trans. 2019, 48, 2582-2591. [CrossRef]

46. Bariashir, C.; Wang, Z.; Suo, H.; Muhammad, Z.; Solan, G.A.; Ma, Y.; Liang, T.; Sun, W.-H. Narrow dispersed linear polyethylene using cobalt catalysts bearing cycloheptyl-fusedbis(imino)pyridines; probing the effects of ortho-benzhydryl substitution. Eur. Polym. J. 2019, 110, 240-251. [CrossRef]

47. Wang, Z.; Solan, G.A.; Mahmood, Q.; Liu, Q.; Ma, Y.; Hao, X.; Sun, W.-H. Bis(imino)pyridines incorporating doubly fused eight-membered rings as conformationally flexible supports for cobalt ethylene polymerization catalysts. Organometallics 2018, 37, 380-389. [CrossRef]

48. Wang, Z.; Zhang, R.; Zhang, W.; Solan, G.A.; Liu, Q.; Liang, T.; Sun, W.-H. Enhancing thermostability of iron ethylene polymerization catalysts through $N, N, N$-chelation of doubly fused $\alpha, \alpha^{\prime}$-bis(arylimino)-2,3:5,6-bis(hexamethylene)pyridines. Catal. Sci. Techn. 2019. [CrossRef] 
49. Huang, F.; Xing, Q.; Liang, T.; Flisak, Z.; Ye, B.; Hu, X.; Yang, W.; Sun, W.-H. 2-(1-Aryliminoethyl)-9-arylimino-5,6,7,8-tetrahydrocycloheptapyridyl iron(II) dichloride: Synthesis, characterization, and the highly active and tunable active species in ethylene polymerization. Dalton Trans. 2014, 43, 16818-16829. [CrossRef] [PubMed]

50. Sun, Z.; Yue, E.; Qu, M.; Oleynik, I.V.; Oleynik, I.I.; Li, K.; Liang, T.; Zhang, W.; Sun, W.-H. 8-(2-Cycloalkylphenylimino)-5,6,7-trihydro-quinolylnickel halides: Polymerizing ethylene to highly branched and lower molecular weight polyethylenes. Inorg. Chem. Front. 2015, 2, 223-227. [CrossRef]

51. Tomov, A.K.; Gibson, V.C.; Britovsek, G.J.P.; Long, R.J.; van Meurs, M.; Jones, D.J.; Tellmann, K.P.; Chirinos, J.J. Distinguishing chain growth mechanisms in metal-catalyzed olefin oligomerization and polymerization systems: $\mathrm{C}_{2} \mathrm{H}_{4} / \mathrm{C}_{2} \mathrm{D}_{4}$ co-oligomerization/polymerization experiments using chromium, iron, and cobalt catalysts. Organometallics 2009, 28, 7033-7040. [CrossRef]

52. Jones, D.J.; Gibson, V.C.; Green, S.M.; Maddox, P.J.; White, A.J.P.; Williams, D.J. Discovery and optimization of new chromium catalysts for ethylene oligomerization and polymerization aided by high-throughput screening. J. Am. Chem. Soc. 2005, 127, 11037-11046. [CrossRef] [PubMed]

53. Zhang, M.; Hao, P.; Zuo, W.; Jie, S.; Sun, W.-H. 2-(Benzimidazol-2-yl)-1,10-phenanthrolyl metal (Fe and Co) complexes and their catalytic behaviors toward ethylene oligomerization. J. Organomet. Chem. 2008, 693, 483-491. [CrossRef]

54. Xiao, T.; Hao, P.; Kehr, G.; Hao, X.; Erker, G.; Sun, W.-H. Dichlorocobalt(II) complexes ligated by bidentate 8-(benzoimidazol-2-yl)quinolines: Synthesis, characterization, and catalytic behavior toward ethylene. Organometallics 2011, 30, 4847-4853. [CrossRef]

55. Sheldrick, G.M. SHELXT-integrated space-group and crystalstructure determination. Acta Cryst. 2015, A71, 3-8.

56. Sheldrick, G.M. Crystal structure refinement with SHELXL. Acta Cryst. 2015, C71, 3-8.

Sample Availability: Samples of the organic compounds and cobalt complexes are available from the authors.

(C) 2019 by the authors. Licensee MDPI, Basel, Switzerland. This article is an open access article distributed under the terms and conditions of the Creative Commons Attribution (CC BY) license (http:/ / creativecommons.org/licenses/by/4.0/). 